\title{
Ideologija desnog radikalizma i populizma u Hrvatskoj: studija slučaja Hrvatske stranke prava
}

\begin{abstract}
Autor u radu na temelju dostupnih arhivskih izvora, tiska i relevantne literature analizira i prikazuje ideologiju Hrvatske stranke prava (HSP). Riječ je o stožernoj pravaškoj, ali i desnoj stranci hrvatskoga političkog života i stranačkog sustava. Koristeći se teorijskim okvirom nizozemskog politologa Casa Muddea o ideologiji radikalne desnice koju čine nativizam, autoritarnost i populizam, autor zaključuje da HSP zadovoljava sva tri kriterija desnog radikalizma, čime se može smatrati da je riječ o stranci radikalne desnice.
\end{abstract}

\section{Uvod}

Predmet je ovog rada ideologija Hrvatske stranke prava (HSP). Desne političke stranke nazočne su u hrvatskome stranačkom sustavu i političkom životu od osamostaljenja Hrvatske. Iako je istraživanje desnih političkih stranaka jedna od najproučavanijih tema u politologiji, hrvatska politologija pokazala je slabo zanimanje za navedeno i nije bila znanstveno obrađivana. ${ }^{1} \mathrm{U}$ radu se polazi od hipoteze kako je HSP tipski primjer radikalno desne stranke u hrvatskome stranačkom sustavu i političkom životu, koja je od 1991. do 2011. bila zastupljena i u Hrvatskom saboru. Radikalni desni elementi osobito su nazočni u javnim nastupima među simpatizerima stranke, kada se koketira s ustaškim pokretom i Nezavisnom Državom Hrvatskom (NDH). Osnova je stranačke ideologije radikalni hrvatski nacionalizam, pri čemu si vodstvo stranke prisvaja monopol na jedino ispravno tumačenje hrvatskih nacionalnih interesa, nazivajući se braniteljima hrvatskog naroda od etabliranih stranaka i vjerujući u čvrsto organiziranu i autoritarnu državu. Rad je podijeljen na šest dijelova. U prvim dvama uspostavljen je teorijsko-metodološki okvir rada. Ostala četiri dijela longitudinalno analiziraju i prikazuju ideologiju HSP-a s obzirom na promjene društveno-političkog, ali i stranačkog konteksta.

1 Iz hrvatske politološke bibliografije mogu se navesti radovi GRDEŠIĆ 1999; OBUĆINA 2012 i eventualno JOŽANC I RAOS 2011. Zanimljivo, ali niti jedan rad nije napisan na hrvatskome jeziku. 


\section{Teorijski okvir desnog radikalizma Casa Muddea}

U Europi je posljednjih nekoliko desetljeća zabilježen znatan rast izbornih uspjeha stranaka radikalne desnice. Neke su od najpoznatijih: francuska Nacionalna fronta, nizozemska Slobodarska stranka, mađarski Jobbik, Alternativa za Njemačku, Srpska radikalna stranka te Slobodarska stranka Austrije koja je početkom 2000-ih bila - a i danas je - dio parlamentarne većine. Kao što je navedeno na početku rada, to je jedna od najistraživanijih politoloških tema. Međutim, problem je u definiranju i terminologiji jer u recentnoj politološkoj literaturi o desnici Cas Mudde navodi da postoje čak 23 termina, a takvo olako korištenje različitim terminima kao istoznačnicama unosi zbrku i stvara koncepcijsku nedosljednost. Među terminima u znanstvenoj literaturi, ali i medijskom diskursu najviše dominiraju ekstremna desnica i radikalna desnica. Razlika između njih ipak postoji. Tako se radikalnom desnicom označavaju one stranke ili pokreti koji prihvaćaju i djeluju unutar demokratsko-liberalnog sustava, dok, s druge strane, ekstremna desnica to ne prihvaća i služi se nasiljem. ${ }^{2} \mathrm{U}$ dijelu politološke literature postoji i teza koja polazi od toga da termini poput radikalne desnice ili ekstremne desnice označavaju zapravo pojavu neofašizma koja se tako ne imenuje radi političke korektnosti. ${ }^{3}$ Kritiku prema mišljenju da je suvremena radikalna desnica jednaka fašističkim strankama iz međuratnog razdoblja dao je Cas Mudde. Prema njemu su suvremene radikalno desne stranke, za razliku od fašističkih stranaka, drugačije po organizacijskoj strukturi i ideološkim obilježjima jer su one danas nativističke, populističke i barem načelno demokratske, za razliku od fašističkih stranaka koje su bile rasističke, elitističke i autokratske. „Drugim riječima, baš kao što je povijesna krajnja desnica odražavala ideološke i organizacijske trendove 1930-ih, protudemokratske stavove i masovnu mobilizaciju, suvremene su stranke plod današnjeg doba u kojem demokracija uživa hegemonijski status, a političke stranke postale su distancirani, profesionalizirani strojevi za izborno natjecanje“". Upravo je nizozemski politolog Cas Mudde trenutno najrelevantniji autor koji se bavi ideologijom radikalne desnice, koja u svojoj teoriji identificira minimalna i maksimalna obilježja stranaka radikalne desnice. Pod minimalnim obilježjima koje imaju sve desne stranke Mudde navodi nacionalizam i nativizam. U njoj je nacija središnji okvir desnih stranaka, iz koje proizlazi prvo obilježje ideologije radikalne desnice - nacionalizam. Drugo je obilježje nativizam, koji se najčešće rabi kao sinonim za antiimigrantske pokrete okrenute protiv stranaca. ${ }^{5} \mathrm{U}$ maksimalnoj definiciji suvremenu ideologiju radikalne desnice čine nativizam, autoritarnost

\footnotetext{
ZGURIĆ 2014: 92.

MILARDOVIĆ 1997: 79; LALOVIĆ 2015: 18; BADOVINAC 2015: 11.

4 MUDDE 2014: 16.

5 ISTI 2007: 16-17.
} 
i populizam. ${ }^{6}$ Za razumijevanje ideologije radikalne desnice ključan je pojam nativizma koji Mudde definira kao ,ideologiju koja drži kako države trebaju biti naseljene isključivo članovima 'nativne' (domicilne, urođene) skupine (nacije) i da 'ne-nativni' (nedomicilni, neurođeni) elementi (osobe i ideje) predstavljaju temeljnu prijetnju homogenoj nacionalnoj državi“ “. Navedena definicija nativizma čini središnji dio ideologije radikalne desnice. Nativizam kao ideologija uključuje elemente nacionalizma i ksenofobije. Njima se pridodaje i šovinizam države blagostanja - u ovom smislu protekcionizam prema članovima vlastitog naroda, a isključivanje stranaca koji se koriste uslugama države blagostanja. Pritom Mudde smatra kako je nativist prikladniji pojam od, primjerice, nacionalista, antiimigranta ili rasista. Nacionalizam i ksenofobiju kao elemente nativizma Mudde je također definirao. Ksenofobija je tako „strah, mržnja ili neprijateljstvo prema skupinama koje se percipiraju kao strane, kao što su primjerice stranci, imigranti, tražitelji azila i slično. Osnovna je ideja da je sve što je strano prijetnja“ “. ${ }^{8}$ Oslanjajući se na radove Ernesta Gellnera i Erica Hobsbawma, Mudde nacionalizam definira kao ,političku doktrinu koja teži podudarnosti kulturne i političke zajednice, na primjer nacija i država“. Drugim riječima, ključni je cilj nacionalizma postići monokulturnu državu. ${ }^{9}$ U tom smislu Mudde misli na etnički nacionalizam u kojem se etnička zajednica smatra ,primarnom/temeljnom jedinicom, dok se država smatra političkom voljom etničke zajednice. Članstvo etničke zajednice temeljeno je na etničkim kriterijima kao što su načelo podrijetla i narodnosti““. ${ }^{10}$ Takav nacionalizam polazi, dakle, od uvjerenja da je smisao svake nacije uspostava ekskluzivne nacionalne države prema načelu ,cijela nacija, jedna država“. Oslanjajući se na rad Koena Kocha, Mudde navodi da je postizanje tog cilja moguće iz dvaju razloga. Prvi je ,unutarnja homogenizacija, koja se može postići na razne načine poput primjerice separatizma, asimilacije, protjerivanja ili čak genocida. Drugi je vanjska ekskluzivnost koja podrazumijeva povratak članova određene nacije izvan granica u matičnu nacionalnu državu“. ${ }^{11}$

Autoritarnost je drugo obilježje ideologije radikalne desnice u teoriji Casa Muddea. Ona podrazumijeva ,vjeru u čvrsto organizirano društvo, dok se njegovo nepoštivanje treba oštro kazniti. Autoritarnost dakle uključuje čvrst 'zakon $i$ red' te 'tradicionalni kazneni moralizam'. Pored toga, autoritarnost sama po sebi nema antidemokratske tendencije, ali ih ne isključuje“. ${ }^{12}$ Programatski,

\footnotetext{
Isto: $22-23$.

Isto: 19.

8 ISTI 2000: 188.

9 ISTI 2007: 16.

10 ISTI 2000: 188.

11 ISTI 2007: 16.

12 Isto: 23.
} 
ona uključuje, primjerice, jačanje vojske i policijskih snaga te stroži pravosudni sustav. ${ }^{13}$ Populizam je treće obilježje u ideologiji radikalne desnice u teoriji Casa Muddea. Populizam je tako definiran kao politička ideologija koja dijeli društvo na dvije antagonističke i homogene skupine: „obični narod“ i „korumpiranu elitu“", te smatra kako politika treba biti izraz opće volje naroda. ${ }^{14}$ Ako je riječ o desnom spektru, populistička desnica bazira se na kritici migracijskih tijekova i multikulturalnih društava, globalizacije te naglašenoj ksenofobiji i obrani nacionalnog i kulturnog identiteta. ${ }^{15}$ Desne populističke stranke dijele osobinu ograđivanja od etničkih i kulturnih manjina na horizontalnoj razini, dok se na vertikalnoj sukobljavaju s već spomenutim elitističkim strukturama. Prema Muddeu, desni populisti razlikuju četiri tipa neprijatelja. Prvi su tip neprijatelji izvan države i izvan nacije - tu su članovi međunarodnih organizacija, stranih vlada, strani kapital itd. Drugi su tip neprijatelji izvan nacije, a unutar države - na meti su imigranti, osobito oni s drugačijom kulturološkom pozadinom, kao i nacionalne manjine. Treći su tip neprijatelji izvan države, a unutar nacije - obuhvaćeni su umjetnici, političari i intelektualci koji su emigrirali u strane zemlje, kao i pripadnici iste nacije koji žive u drugoj državi, ali ne teže ujedinjenju s matičnom državom. Četvrti su tip neprijatelji unutar nacije i unutar države - odnosi se na neodređen pojam elite koja predstavlja amalgam kulturnih, političkih i ekonomskih aktera, nacionalne izdajnike koji su u službi stranih interesa i izopačenih pojedinaca poput homoseksualaca i narkomana. ${ }^{16}$ S druge strane, etablirane političke stranke imaju četiri strategije kojima se koriste kako bi pokušale zaustaviti jačanje populista. Prva je izolacija, koja podrazumijeva odbacivanje koalicije s populistima koji se smatraju demagozima i protudemokratima, čiji su zahtjevi nerealni i/ili nelegitimni. Druga je sukob - ima ista obilježja kao prva, no u njoj se populisti žestoko napadaju u političkome životu. Treća je prilagodba, gdje etablirane političke stranke prihvaćaju neke populističke zahtjeve i ugrađuju ih u svoje programatsko djelovanje te tako slabe populiste. Četvrta je socijalizacija, koja nastojati pacificirati populiste nudeći im sudjelovanje u vlasti, tražeći pri tome da zauzvrat odustanu od svojih najradikalnijih zahtjeva. ${ }^{17}$ Nativizam, autoritarnost i populizam usko su povezani s trima (za stranke radikalne desnice) glavnim političkim pitanjima: imigracijom, kriminalom i korupcijom. U tom smislu stranke radikalne desnice ne možemo smatrati jednoproblemskim strankama. ${ }^{18}$

\footnotetext{
Isto: $146-150$.

14 Isto: $22-23$.

15 BEYME 2007: 28; MILARDOVIĆ 2004: 204.

16 MUDDE 2007: 64-78.

17 MUDDE I KALTWASSER 2013.

18 MUDDE 2012: 9.
} 
Teorijski okvir Casa Muddea najrelevantniji je iz nekoliko razloga. Prvi je taj što određuje zajednička obilježja u ideologiji stranaka radikalne desnice. Drugi je specifičnost upotrebe pojma nativizam koji se ne koristi široko u politološkoj literaturi. Treći je suvremenost njegove definicije populizma. Četvrti je općenitost jer se primjenjuje za sve europske desne stranke, a ne samo na one iz Europske unije. Peti je osvojena nagrada „Stein Rokkan“ iz 2008. za objavljenu monografiju Populist Radical Right Parties in Europe, u kojoj je izložio svoj teorijski okvir. „Riječ je o nagradi koju u spomen norveškom politologu i sociologu Rokkanu dodjeljuju Međunarodno vijeće zadruštvene znanosti, Sveučilište u Bergenu i Europski konzilij za politološka istraživanja“ ${ }^{19}$ U konačnici, navedeni teorijski okvir prihvatili su i koriste se njime u svojim studijama i hrvatski politolozi. Međutim, ne upotrebljavaju ga za analizu hrvatske politike, već međunarodne: Srbija ${ }^{20}$, Mađarska i Nizozemska. ${ }^{21}$

\section{Ciljevi i metodologija istraživanja}

Za oblikovanje istraživanja ovog rada odabrana je studija slučaja kao jedan od tipova metoda istraživanja politike. Riječ je o specifičnoj istraživačkoj strategiji koja se vrlo često koristi i metodama kvalitativnog pristupa, a učestalo se primjenjuje i u doktorskim radovima iz društveno-humanističkih znanosti. ${ }^{22}$ „Studije slučaja omogućuje istraživaču da se fokusira na jednog pojedinca, grupu, zajednicu, događaj, područje javnih politika ili institucija, te da ih podrobno prouči, možda tijekom duljeg razdoblja“'.23

U sklopu ove studije slučaja fokus će biti na političkoj stranci HSP i pokušat će odgovoriti na dva istraživačka pitanja: kako su promjene političkoga i društvenoga konteksta u prvim dvama desetljećima samostalne hrvatske države utjecale na kontinuitet ili diskontinuitet $\mathrm{u}$ stranačkoj ideologiji te postoje li u djelovanju HSP-a elementi ideologije desnog radikalizma prema teorijskom okviru Casa Muddea. S obzirom na različite studije slučaja (eksplanatorna, koja utvrđuje uzročno-posljedične odnose; eksploratorna, kojom se prikupljaju informacije i nalazi o kojima ne postoje prethodna znanstvena istraživanja, čime se upoznaje i dobiva uvid u problem; deskriptivna, koja opisuje određene pojave, čime se dobiva njezin opći uvid), prvenstvo u odabiru imat će posljednja, deskriptivna, jer će podrobno opisati i analizirati političku ideologiju HSP-a, no kako nije moguće nikada uspostaviti čiste idealtipove u praksi, ova studija slučaja sadrži također

\footnotetext{
9 VESELINOVIĆ 2017: 72.

20 ESTERAJHER 2012.

21 ZGURIĆ 2014.

22 YIN 2007: 5.

23 BURNHAM, GILLAND, GRANT I LAYTON-HENRY 2006: 56.
} 
elemente eksploratorne i eksplanatorne analize, posebno ondje gdje odgovara na postavljene hipoteze ovog rada. ${ }^{24}$

Muddeova obilježja ideologije radikalno desnih stranaka rekonstrukcijom djelovanja HSP-a operacionalizirat će se na sljedeći način. Kao indikator nativizma koristi se odnos HSP-a prema srpskoj nacionalnoj manjini i njezinim političkim predstavnicima na temelju stranačkog programa i medijskog diskursa. Riječ je ne samo o najbrojnijoj nacionalnoj manjini već i o dugom povijesnom naslijeđu dijametralno suprotnih stavova između pravaške ideologije i (veliko)srpske političke ideologije i politike. Postojanje nativizma može se ustanoviti u slučaju nazočnosti indikatora etničkog nacionalizma, u kojem HSP zastupa uvjerenje da je smisao hrvatske nacije uspostava ekskluzivne nacionalne države prema načelu ,cijela nacija, jedna država“. U tom se smislu država smatra političkom voljom etničke zajednice, čije se članstvo temelji na etničkim kriterijima kao što su načela zajedničkog povijesnoga podrijetla, mitova, sjećanja, narodnosti, jezika i razlikom prema drugima. Takva eksluzivna hrvatska nacija uključivala bi i manjinske pripadnike njihovom asimilacijom ili etničkim protjerivanjem ako ne budu suglasni s asimilacijom. Za postojanje obilježja autoritarnosti analizirat će se stranačka organizacija i politički program HSP-a. Postojanje autoritarnosti može se ustanoviti u slučaju nazočnosti indikatora visoko centralizirane i hijerarhijske organizirane stranke, čija je vlast $u$ strogo kontroliranim rukama jakog vođe. Stranačka čvrsta organizacija pokazala bi kako bi cijelo društvo izgledalo u cjelini. Drugi je indikator militarizam. Njime se označava ideja koja zagovara jačanje državne vojne moći. Navedeno predstavlja jednu od središnjih tema kojima stranke radikalne desnice programatski daju na važnosti. Za postojanje obilježja populizma analizirat će se parlamentarne izborne kampanje HSP-a koje predstavljaju najintenzivnije razdoblje političke komunikacije koja se odvija među političkim akterima, medijima i javnosti, ali i cjelokupna stranačka ideologija i političko djelovanje kako bi se potpuno utvrdilo jesu li suvremeni pravaši populisti. Indikatori koji prepoznaju populizam jesu sljedeći. Najprije će se utvrditi koliko se često u stranačkoj retorici, programu i djelovanju koristi izraz narod jer je pozivanje na narod i suprotstavljanje etabliranim političkim elitama središnja jezgra stranačkog programa i retorike u populista. Ova je analiza nužna jer treba odgovoriti na pitanje može li se neka stranka smatrati populističkom. ${ }^{25}$

${ }_{24}$ Robert K. Yin definira studiju slučaja kao empirijsko istraživanje koje ,proučava suvremeni fenomen unutar njegovog stvarnog životnog konteksta, posebno kada granice između fenomena i konteksta nisu očite" (YIN 2007: 24). Drugim riječima, opravdanost odabira studije slučaja odražava se u tome jer nema kontrole nad događajima i jer je tema suvremena, što je dodatan razlog opravdanosti metodološkog odabira. U konačnici, specifičnost je studije slučaja u tome da neposredno komunicira s teorijski oblikovanim hipotezama i da testira teoriju koju može potvrditi ili odbaciti. To je, uz nedostatnu strogost, dugi rok i opširan sadržaj, jedna od predrasuda prema studiji slučaja jer su one „poopćive s obzirom na teorijske pretpostavke, a ne na populacije ili univerzume“" (Isto: 21$)$.

25 ŠALAJ 2013: 19. 
Zatim će se analizirati kako se shvaća narod. Populisti sebe predstavljaju kao „malog običnog čovjeka“ koji se izjednačava s narodom i gleda na njega kao na homogenu skupinu. Treći je indikator nepovjerenje „običnog i poštenog naroda“ prema „korumpiranim elitama“. To je središnja ideja populizma. Zbog toga je potrebno istražiti tko predstavlja elitu, naročito političku, i tko su „opasni Drugi“ koji narušavaju homogenost naroda. Četvrti je indikator nazočnost jakog stranačkog i karizmatskog vođe koji ističe svoju izravnu vezu s narodom predstavljajući se njegovim spasiteljem. Posljednji, peti indikator jest koncept zazivanja izravne demokracije i njegovih instrumenata - primjerice, referendumima i peticijama. To je logičan pokazatelj jer populisti smatraju kako su političke institucije korumpirane od strane elita.

Sva tri obilježja ideologije desnog radikalizma u Muddeovoj teoriji operacionalizirat će se metodom analize sadržaja na temelju stranačkih dokumenata (programi, politička načela, deklaracije, statuti, izborni materijali), kao i novinskih priloga o HSP-u tijekom parlamentarne izborne promidžbe, računajući i intervjue vodećih stranačkih dužnosnika koje su davali novinama i u novije vrijeme internetskim portalima. Analiza je sadržaja u najširem smislu ,postupak proučavanja i raščlanjivanja nekog pisanog ili slikovnog materijala kojim se nastoje uočiti neke osobine odnosno poruke toga sadržaja“ “. ${ }^{26}$ Postoje dvije vrste analize sadržaja: kvalitativna, u kojoj važnost sadržaja određuje istraživač na temelju vlastite prosudbe i ekspertize, te kvantitativna, koja utvrđuje učestalost jedinica analiza (primjerice, korištenje riječju narod za obilježje populizma), a definira se kao tehnika istraživanja „za objektivan, sustavan, i kvantitativan opis vidljivog sadržaja komunikacije“ ${ }^{27}$ Obje će se primijeniti u radu, iako će prvenstvo imati kvalitativna, uz postojanje elementarne kvantifikacije, npr. frekvencije pojavljivanja indikativnih pojmova i narativa. Opravdanost je analize sadržaja u tome što se često koristi za analiziranje politike političkih stranaka. ${ }^{28}$ Medijski sadržaj koji će se posebno za politološku rekonstrukciju analizirati jesu dnevne političke novine s dugom povijesnom tradicijom, Vjesnik, i jedne od najčitanijih dnevnih novina, Večernji list, tijekom trajanja službene izborne kampanje za Sabor u razdobljima: 11. - 31. srpnja 1992., 8. - 27. listopada 1995., 14. prosinca 1999. - 1. siječnja 2000., 5. - 21. studenoga 2003., 2. - 23. studenoga 2007. i 17. studenoga -2. prosinca 2011. godine. U istraživanim je periodima objavljeno ukupno 102 priloga o HSP-u, od čega je 11 intervjua vodećih stranačkih dužnosnika. Analiza će se provesti prema indikatorima koji su proizašli iz teorijskog dijela rada. Tako će se politološki analizirati postoje li - i ako postoje, u kojoj mjeri - obilježja ideologije desnog radikalizma u HSP-u. Iako se u radu koristila i stranačka arhiva

26 LAMZA POSAVEC 2006: 178.

27 BURNHAM, GILLAND, GRANT I LAYTON-HENRY 2006: 56.

28 Isto: 253. 
kao primarni izvor u historiografiji, ona se nije mogla u potpunosti iskoristiti zbog nedostatka sadržaja za analizu, stoga su velik oslonac bili sekundarni, odnosno tiskani izvori.

Na izvorima desnog radikalizma, 1990. - 1993.

Uspostava višestranačkog sustava u Hrvatskoj dovela je, pored osnivanja novih stranaka, i obnavljanje nekih starih koje su se imenom pozivale na povijesnu tradiciju. Jedna od njih bio je HSP, za čijeg je predsjednika izabran bivši politički zatvorenik i disident Dobroslav Paraga. Pod njegovim vodstvom od obnavljanja stranke 1990. do velikog unutarstranačkog raskola iz 1993. javni i politički diskurs HSP-a naglašavao je antikomunizam, protujugoslavenstvo, odnosno neprijateljski stav prema jugoslavenskoj političkoj ideji i državi, „srpsko pitanje“, hrvatski nacionalizam i neprijateljstvo prema staroj i novoj političkoj eliti. ${ }^{29}$ Nativizam je imao značajnu ulogu u politici HSP-a. Programatski, pravaški cilj bio je uspostava samostalne hrvatske države. Pozivajući se na svoje povijesno naslijeđe, HSP je preuzeo i pravaško geslo „Hrvatska Hrvatom (Hrvatima)“. Pravaški nacionalizam u skladu s njegovom izvornom tradicijom i pozivanjem na vrijednosti Francuske revolucije bio je građanski, u kojem su se svi građani smatrali Hrvatima u političkome smislu. Međutim, budući da su nacije bile konstituirane na južnoslavenskome prostoru prema etnokulturalnom načelu te s obzirom na kontekst rata i stvaranja samostalne države na početku 1990-ih, suvremeni pravaški politički diskurs bio je vjerojatno svjestan promjene okolnosti. Zbog toga je u političkome diskursu i nastupima pravaški nacionalizam de facto ipak bio etnički, u kojem se zastupalo uvjerenje da je smisao hrvatske nacije uspostava ekskluzivne nacionalne države prema načelu ,jedna nacija, jedna država“ ili, možda još preciznije, ,cijela nacija, jedna država“. Takvo uvjerenje podrazumijevalo je i teritorijalni revizionizam, odnosno proširivanje hrvatskih granica na druge države, naročito Bosnu i Hercegovinu $(\mathrm{BiH})$ te Srbiju i Crnu Goru, što pokazuje maksimalistički program pod nazivom „Lipanjska povelja“ koji je HSP donijela 13. lipnja 1991., čije su istočne granice pravaške Velike Hrvatske bile Subotica, Zemun, Drina, Sandžak i Boka kotorska. ${ }^{30}$ Pravaši su taj cilj htjeli ostvariti kroz način vanjske ekskluzivnosti koja podrazumijeva povratak Hrvata izvan granica u matičnu nacionalnu državu. U „Temeljnim načelima HSP-a“ iz 1991. stoji kako je uzrok iseljavanja Hrvata njihovo sustavno ugnjetavanje i teško materijalno stanje, što za posljedicu ima zastrašujuću činjenicu „da jedna polovica Hrvata živi u inozemstvu, dok se u Hrvatsku trajno useljava nehrvatsko stanovništvo“, zbog čega će se HSP „zalagati da se svim Hrvaticama i Hrvatima omogući povratak na njihova pradjedovska

29 VESELINOVIĆ 2014.

30

Isto: 67. 
ognjišta, kako bi mogli što učinkovitije pridonositi obnovi i procvatu lijepe naše domovine“". ${ }^{31}$ Upravo je uz kapital iseljenih Hrvata jedan od obnovitelja i dopredsjednik HSP-a Ante Paradžik vezao hrvatski gospodarski napredak. ${ }^{32}$ Iz navedenog može se zaključiti da je cilj HSP-a ekonomska samodovoljnost Hrvatske, odnosno protekcionizam davanjem hrvatskome kapitalu prednost pred stranome koji se isključuje, a njime i strano vlasništvo. Paraga je tijekom izborne kampanje 1992. naglašavao da je HSP ,isključivo za čistu Hrvatsku, za Hrvatsku bez komunista, za Hrvatsku bez Srba-Velikosrba“. ${ }^{33}$ Pravaško viđenje ekskluzivne hrvatske nacionalne države uključivalo je i način unutarnje homogenizacije, prvenstveno asimilacijom, naročito one najbrojnije - srpske. Asimilacija je tako programatski bila predviđena uspostavljanjem autokefalne Hrvatske pravoslavne crkve za pravoslavno stanovništvo, što je, naravno, značilo ukidanje Srpske pravoslavne crkve u hrvatskoj državi. ${ }^{34}$ U HSP-u smatrali su da to „neće povrijediti nijednog poštenog pravoslavca“. ${ }^{35}$ Osnivanje Hrvatske pravoslavne crkve bilo je u skladu s izvornim pravaštvom Ante Starčevića i Eugena Kvaternika, međutim, zaživjelo je jedino za vrijeme NDH i njezina represivnog i zločinačkog ustaškog režima. Hrvatski su Srbi, prema Paragi, mogli biti „samo Hrvati, hrvatski državljani, voljeti Hrvatsku, boriti se bolje nego oni koji su porijeklom Hrvati za tu Hrvatsku. Svatko tko drukčije misli ići će u Srbiju, ili gdje ih prime, a vidim da Srbe više nitko nigdje neće. Mi smo posljednji koji bi takve htjeli na ovom području (...) Mi imamo rješenje za njih, sviđalo im se to ili ne. Oni koji su za Hrvatsku to su već pokazali. Oni su za mene osobno jednaki kao Hrvati“ ${ }^{36} \mathrm{U}$ djelovanju dijela pravaša bio je vidljiv i element sklonosti prema protjerivanju. Inspektor HOS-a Mile Dedaković tako je eksplicitno izjavio da ,čim HSP dođe na vlast 50\% Srba morat će iz Hrvatske. U njoj će moći ostati samo oni Srbi koji su je branili, a u Zagrebu, Kninu i Vukovaru više neće biti suživota“, te da „tko želi suživot sa Srbima neka ide u Niš i Surdulicu“ $\cdot{ }^{37} \mathrm{U}$ tom je smislu pravaški javni diskurs naglašavao „srpsko pitanje“ u kojem su otvoreno bili neprijateljski nastrojeni prema dijelu srpske populacije, osobito prema velikosrpskoj politici i pobunjenicima iz Srpske demokratske stranke (SDS). Razlog tomu može se gledati u kontekstu stvaranja države, velikosrpske agresije na Hrvatsku, ali i nazočne ustašonostalgije u stra-

31 Pismohrana Hrvatske stranke prava (PHSP): Statut i temeljna načela Hrvatske stranke prava, 29.

32 PARAGA I PARADŽIK 1991: 27.

33 Rat je tek počeo. Večernji list, 14. srpnja 1992.

34 PHSP: Statut i temeljna načela Hrvatske stranke prava, 33.

35 PHSP: Proglas HSP-a o sadašnjem predsjedniku Republike.

36 Ni moja se žena neće voziti u državnom autu. Novi Vjesnik, 11. srpnja 1992.

37 Nećemo ružičastu Hrvatsku. Novi Vjesnik, 14. srpnja 1992.; Rat je tek počeo. Večernji list, 14. srpnja 1992. 
načkoj identifikaciji. ${ }^{38}$ Zbog toga su pravaši smatrali da je veći dio srpske etničke zajednice trajni neprijatelj, opasnost i prijetnja samostalnoj hrvatskoj državi. Za to je bila zaslužna i segregacijska politika SDS-a, zbog čega je glavni tajnik HSP-a Krešimir Pavelić smatrao kako je Hrvatska demokatska zajednica (HDZ) kao vladajuća stranka trebala povesti postupak da se SDS isključi iz Sabora jer je to faktički teroristička stranka. ${ }^{39}$ Izrazito radikalan stav imao je dopredsjednik HSPa Ante Paradžik, koji je naglašavao da nakon poraza „velikosrpske-boljševičke ideje hrvatski i srpski narod više ne mogu živjeti u jednoj državi. Srpski i hrvatski narod moraju imati samostalne države, jer to jamči sreću i jednom i drugom, a granice između naših država moraju biti na rubu njihova etničkog i povijesnog prostora. To znači da su granice Hrvatske na Drini, a granice Srbije beogradski pašaluk, odnosno granica velike Šumadije“. ${ }^{40} \mathrm{U}$ svojim nastupima pojedini su pravaški prvaci poput K. Pavelića barem deklarativno isticali kako prave razliku između velikosrpske politike i hrvatskih Srba. „Nemojmo misliti da je Jovan Rašković prvak ili predstavnik svih hrvatskih Srba. Kao što pop Đujić nije klao u ime svih Srba nego samo u ime velikosrba, dakle četnika, koji su imali za cilj uništiti hrvatski narod i stvoriti Veliku Srbiju. Ja se nadam da će se u Hrvatskoj uskoro naći takva osoba koja će biti pravi predstavnik Srba u Hrvatskoj, koja će braniti Hrvatsku kao svoju domovinu i boriti se za njezinu nezavisnost. Ukoliko do toga ne dođe onda to gore za same Srbe, jer će Hrvatska biti nezavisna htjeli to oni ili ne" “. ${ }^{41}$ Međutim, K. Pavelić smatrao je da hrvatski Srbi žele hegemoniju nad Hrvatima i privilegije koje su imali tijekom povijesti. ${ }^{42}$ Prema Paragi, uzrok sukoba hrvatskih Srba i Hrvata vidio je u vladavini komunista koji su toliko zatrovali te odnose „da ne vidim razloga zašto još postoje, zašto se ne maknu s pozornice“, smatrajući da su interesi obaju naroda zajednički jer ,„̌iivimo u istoj domovini i možemo biti mirni i dobri susjedi i prijatelji““. ${ }^{43}$ Paradžik je smatrao da je za pobunu dijela hrvatskih Srba odgovoran Beograd i Memorandum Srpske akademije nauka i umetnosti, koji kao taktiku koriste „Srbe u Hrvatskoj za svoju velikosrpsku politiku““. ${ }^{44}$ Ideal pravaša bila je samostalna hrvatska država. To je značilo odbijanje bilo kakve južnoslavenske ideje i države, smatrajući je pogubnom za Hrvate. Paraga je tako eksplicitno zastupao uvjerenje da je za HSP Jugoslavija „tamnica i grobnica hrvatskog naroda i Jugoslavija mora umrijeti da

\footnotetext{
38 O ustašonostalgiji i politici povijesti HSP-a koja je kroz povijesni revizionizam pozitivno vrednovala NDH detaljno vidi: PAVLAKOVIĆ 2008; BADOVINAC 2015.

39 PARAGA I PARADŽIK 1991: 220.

40 BUTKOVIĆ I GRAKALIĆ 1992: 39.

41 PARAGA I PARADŽIK 1991: 127.

42 Isto: 126.

43 Isto: $112,155$.

44 Ubija svatko svakoga. Danas, 1. listopada 1991.
} 
bi hrvatski narod mogao ponovno živjeti“ te da je „Hrvatska previše opljačkana od Jugoslavije da bi nas u njoj više ikakva sila mogla zaustaviti“ “. ${ }^{45}$ Pravaši su, naravno, osuđivali obje Jugoslavije (monarhističku te komunističku) ${ }^{46} \mathrm{U}$ izbornom proglasu 1992. navedeno je da će hrvatskim Ustavom ,svi politički procesi koji su vođeni u Karađorđevićevoj i Titovoj Jugoslaviji biti poništeni““. ${ }^{77}$

Autoritarnost se u HSP-u također ogledavala u kontekstu rata. U tom su smislu pravaši bili pristaše militarizma, zagovarajući veliku i moćnu vojsku koja je u stanju braniti nacionalnu državu. Tijekom 1991. HSP je otvoreno iskazivao želju da vodi Ministarstvo obrane. ${ }^{48}$ Tome treba dodati osnivanje paravojnih stranačkih postrojbi Hrvatskih obrambenih snaga (HOS) koje su djelovale u Domovinskom ratu. ${ }^{49} \mathrm{~S}$ obzirom na kontekst rata, Paradžik je zastupao stav da je potrebno cijelo gospodarstvo podrediti ratu, što je podrazumijevalo proizvodnju oružja, te da bi hrvatske vojne snage trebale biti ,ofenzivnije i ambicioznije, kako bi se rat preselio na teritorij Srbije, i to na područje Niša, Bora, Zaječara i Vranja. Tada bi agresor na vlastitoj koži osjetio ratna razaranja ${ }^{\text {. }}{ }^{50}$ Identično je u medijima tijekom izborne kampanje nastupao i Paraga. Kada je u pitanju stranačka organizacija, prema prvome Statutu iz 1991., položaj predsjednika HSP-a nije mu jamčio velike ovlasti. Međutim, situacija se promijenila izbijanjem rata, kada je Paragu Predsjedništvo HSP-a ovlastilo da i uime Predsjedništva obavlja sve radnje koje su u okviru prava i dužnosti označenih u stranačkom Statutu, a u skladu s programskim načelima stranke. ${ }^{51}$ Time se može smatrati da je koncentrirao moć u svojim rukama. Paraga se može opisati kao autoritaran vođa zbog načina na koji se nosio s unutarstranačkom oporbom jer se eliminacijama i taktičkim nadmudrivanjem vrlo lako riješio otvorenih kritičara i „unutarnjih neprijatelja“ u HSP-u, počevši od obnovitelja stranke poput Gorana Ante Blažekovića, K. Pavelića, preko Tomislava Jonjića, do saborskog zastupnika Ante Prkačina. ${ }^{52}$ Najveći raskol u novijoj pravaškoj povijesti dogodio se sredinom 1993. zbog odnosa prema politici predsjednika Franje Tuđmana i HDZ-a. Paraga je isključivao mogućnost političke suradnje s HDZ-om te je kritizirao politiku predsjednika Tuđmana, dok su članovi Predsjedništva HSP-a Boris Kandare i Anto Đapić bili suprotnog stajališta. ${ }^{53}$ Dvojac

\footnotetext{
45 PARAGA I PARADŽIK 1991: 148, 157.

46 PHSP: Statut i temeljna načela Hrvatske stranke prava, 28-31.

47 PHSP: Proglas HSP-a o sadašnjem predsjedniku Republike.

48 HSP traži Ministarstvo obrane. Večernji list, 16. listopada 1991.

49 VESELINOVIĆ 2014.

50 BUTKOVIĆ I GRAKALIĆ 1992: 37.

51 Osobna pismohrana Stjepana Špehara: Izvod iz zapisnika sa 4.sjednice predsjedništva HSP-a od 11.kolovoza 1991., Zagreb, 24. 8. 1993.

52 O raskolima u HSP vidi: PAVELIĆ 1995; BLAŽEKOVIĆ 2007; JONJIĆ 2013.

53 O odnosu Franje Tuđmana i pravaških političara vidi: VESELINOVIĆ 2016.
} 
je tražio izvanredni sabor stranke jer je smatrao da Paraga svojim autoritativnim vođenjem želi upropastiti HSP. Središnji je odbor stranke prijedlog odbio i podržao Paragu kao predsjednika. ${ }^{54}$ Ubrzo su nakon toga zbog inzistiranja na sazivanju izvanrednog stranačkog sabora, potom zbog odluke da su službeni stavovi HSPa samo oni koji su ovjereni ili izrečeni u nazočnosti i suglasnosti najmanje triju članova Predsjedništva HSP-a - što je bilo u suprotnosti sa Statutom stranke kao i zbog nepoštovanja odluka stranačkih tijela Kandare i Đapić isključeni iz HSP-a. ${ }^{55}$ Unatoč tome, uz podršku vladajućeg HDZ-a i državnih tijela, dvojac je organizacijom izvanrednog sabora stranke u Kutini izvršio stranački puč, gdje su „smijenili“ Paragu i preuzeli HSP, a djelovanje stranke znatno približili HDZ-u, pretvorivši se u njegova desnog satelita u nacionalnome stranačko-političkome sustavu. ${ }^{56}$ Eliminacija Đapićeve frakcije za Paragu nije bila uspješna prvenstveno zato što je Anto Đapić uživao podršku među vladajućom političkom elitom, ali je znakovito da je među razlozima unutarstranačkog raskola bilo i smatranje Đapićeve frakcije da Paraga stranku vodi nestatutarno i autoritarno.

Nadalje, kada je riječ o autoritarnosti, programatski HSP zalagao se za donošenje „Zakona o krivičnom postupku koji će biti jednostavan, a djelotvoran, i prekršajni zakon koji će odgovarati europskim standardima i građanske zakone. Sve će postupke pojednostaviti, a broj službenika uprave razumno smanjiti (...) Korupcija i mito sprečavat će se strogim kaznama“. ${ }^{57}$ Iako se isticalo da neće biti državne religije, zastupao se stav u kojem će država i crkve tijesno surađivati. ${ }^{58}$ Tome treba dodati zalaganje za „,narodnu zajednicu temeljenu na višestoljetnim hrvatskim tradicionalnim duhovnim vrijednostima i na urednom vjerskom $\mathrm{i}$ obiteljskom životu“ ". ${ }^{59} \mathrm{U}$ konačnici, HSP je bio protiv pobačaja iz dvaju razloga. Prvi je zbog zalaganja za zaštitu života od začeća do naravne smrti, a drugi jer je hrvatski narod „u demografskoj pogibelji zbog niskog nataliteta i prevelikog iseljavanja“" ${ }^{60}$ Stoga se isticalo da će se HSP radi biološkog opstanka boriti za gospodarske mjere „koje će poticati rađanje djece i zaštićivati majčinstvo“. ${ }^{61}$

Populizam je također bio nazočan u djelovanju HSP-a pod Paraginim vodstvom. Ključni stranački dokument kojim se utvrđivalo je li HSP uopće populistička

\footnotetext{
54 PHSP: Izvod iz zapisnika sa sjednice Središnjeg odbora HSP-a 31. V. 1993., Zagreb, 11. VI. 1993.

55 PHSP: Rješenje o isključenju Ante Đapića, Borisa Kandarea, Rudolfa Arapovića, Denisa Gotala i Vlade Jukića, Zagreb, 25. VII. 1993.

56 ZAKOŠEK 2002: 44.

57 PHSP: Proglas HSP-a o sadašnjem predsjedniku Republike.

58 Isto.

59 PARAGA I PARADŽIK 1991: 16.

60 PHSP: Statut i temeljna načela Hrvatske stranke prava, 33.

61 PARAGA I PARADŽIK 1991: 16.
} 
stranka bila su „Temeljna načela HSP-a“, koja su donesena na Prvom općem Saboru stranke 1991., a koja su i danas aktualna i važeća jer se bez njihovih prihvaćanja ne može postati članom stranke. Od ukupno 88 rečenica, u njih 18 spominje se izraz hrvatski narod, a u dvjema Hrvati. Pozivanje na narod i govor u njegovo ime osobito je istaknuto u državotvornim načelima. Tako se, primjerice, isticalo da HSP „smatra svojom temeljnom obvezom upornu borbu za obnovu potpune hrvatske državne nezavisnosti, jer hrvatski narod ima neotuđivo pravo da sam vlada na cjelokupnom povijesnom i etničkom prostoru, kao svom državnom području“ . ${ }^{2}$ Nadalje, zastupalo se uvjerenje da prije uspostave potpune hrvatske državne neovisnosti HSP ne prihvaća ,nikakvu državnu zajednicu s drugim državama ili narodima dok o tome neposrednim glasovanjem ne odluči cijeli hrvatski narod“, naglašavajući pri tome kako smatraju „da je svako priznavanje državotvornih prava u hrvatskoj državi bilo kojim drugim etničkim skupinama, posve protivno interesima i stremljenima hrvatskog naroda, pa se - u svezi s time - izričito protivimo svim jugoslavenskim i sličnim ciljevima“" ${ }^{63} \mathrm{Na}$ temelju toga može se zaključiti kako su pravaši pojam naroda primarno poistovjetili s pojmom nacije, što se može nazvati nacionalnim populizmom. Tome valja dodati i 41 objavljen novinski prilog o HSP-u tijekom službene izborne promidžbe 1992., u kojemu se čak 85 puta spomenuo izraz hrvatski narod. Stoga se može nedvojbeno zaključiti da HSP predstavlja populističku stranku. Programatski, pravaši su razdoblje komunističke diktature smatrali lošim za Hrvatsku. Isticali su da će raditi na uklanjanju svih njegovih posljedica, kao i da će ,svim raspoloživim sredstvima sprječavati stvaranje sličnih komunističkih pokreta u Hrvatskoj koji oponašaju i toleriraju srušeno boljševičko jednoumlje izgrađeno na pogubnim uzorima lenjinskog despotizma“. ${ }^{64}$ Držali su da nova vlast nije raskinula s komunističkim naslijeđem. Štoviše, novu političku vlast i elitu smatrali su nastavkom komunizma. Paraga je tako isticao da je HSP ,,antikomunistička stranka koja želi definitivni obračun s titoističkim strankama, koje su samo promijenile boje i simbole, ali je sistem vladavine ostao isti“ “. ${ }^{65}$ Prvaci HSP-a sebe su tijekom izborne kampanje 1992. proglašavali jedinim pravim demokratima i iskazom prave narodne volje, naglašavajući da HSP vjeruje ,hrvatskom narodu, a narod vjeruje njoj“ ili, primjerice, ,... narod je u prilici vidjeti da smo mi na njegovoj strani“ ${ }^{66}$ S̆ Stoviše, proglašavali su HSP djetetom hrvatskog naroda: „HSP stoji pred hrvatskim narodom uzdignuta čela, ta stranka proizašla je iz utrobe hrvatskoga naroda“ ${ }^{67}$ Pravaši su

\footnotetext{
PHSP: Statut i temeljna načela Hrvatske stranke prava, 30.

Isto: 31.

64 Isto: 30.

65 Počinje demokracija. Novi Vjesnik, 31. srpnja 1992.

66 Dovoljno hrabri i drski. Večernji list, 19. srpnja 1992.

67 Crveni karton crvenima. Večernji list, 21. srpnja 1992.
} 
ti koji predstavljaju narod, nasuprot „pokvarene“ političke elite, misleći pritom na vladajući HDZ i Franju Tuđmana: „upozoravali smo HDZ da ne valja put kojim idu, ali oni nisu vjerovali hrvatskom narodu“ " ${ }^{68}$ Navedene je HSP otvoreno proglašavao nacionalnim izdajnicima ili, pravaškim riječima, bili su „slavoserbi“. Tijekom cijele izborne kampanje, ali i čitavog političkog djelovanja pravaški su se prvaci negativno referirali na političku elitu, smatrajući sebe istinskim predstavnikom naroda. Tako je, primjerice, Paraga već tijekom 1991. tvrdio da je politika Tuđmana ,politika nacionalne izdaje, u svakom pogledu. Između njegove politike i politike nacionalne izdaje stoji apsolutni znak jednakosti. Naime, ništa od onoga što je trebalo učiniti nije učinjeno. Da ne govorim da smo sve morali preuzeti na sebe zbog njegove inertnosti“, naglašavajući kako HSP ,jedina govori istinu hrvatskom narodu“ i da je zbog situacije u kojoj se Hrvatska nalazi odgovoran Tuđman, pri čemu je tražio da časno ,podnese ostavku, kako mu kasnije ne bi sudio ni hrvatski narod, ni povijest" ${ }^{69}$ Za izbore 1992. HSP je objavio proglas o Tuđmanu u kojemu je navedeno 19 njegovih grijeha. Između ostalog, proglašen je krivim jer nije pripremao obranu zemlje i imenovao agresora, jer je vjerovao kolegama iz Jugoslavenske narodne armije, jer je doveo Unprofor ${ }^{70}$, jer je izdao Vukovar i dopustio genocid u tom gradu, jer je želio dijeliti BiH i vršiti preseljenje naroda, jer se trudio dokazati kako je NDH fašistička tvorevina, čime je potpomagao jačanje srpsko-židovskog lobija itd. Pritom je poručeno biračima da će, izaberu li Tuđmana, imati prodanu i okupiranu zemlju, laž i diktaturu HDZ-a i Tuđmana koji će blagovati u luksuzu što mu ga je ostavio njegov vođa, učitelj i duhovni otac Tito, ,dok ćeš ti hrvatski narode, u stotinama tisuća prosjački noćivati pod darovnim šatorima“" ${ }^{71}$ Negativno referiranje na vladajuću političku elitu zabilježeno je i u 28 novinskih priloga o HSP-u tijekom trajanja izborne promidžbe. Tako je politička elita povezana i s ratnim zločinima i političkim ubojstvima. Paraga je optuživao Tuđmana da iza ubojstva Ante Paradžika stoji „,vodstvo HDZ$a^{\text {“"72 }}$, dok je za zločine ubijanja Srba u Gospiću naglašavao: „Manoliću, ti si odgovoran za sve što se dogodilo. Kriva je hrvatska vlast. Ja se služim demokratskim sredstvima, a oni zločinima““. ${ }^{73}$ „Oni“" su, naravno, vladajuća, ali i zločinačka politička elita. Da su smatrali kako se vladajuća elita držala otuđenom od naroda,

\footnotetext{
68 Bdijte nad glasačkim kutijama. Večernji list, 26. srpnja 1992.

69 BUTKOVIĆ I GRAKALIĆ 1992: 28.

70 Riječ je o mirovnim zaštitnim snagama Ujedinjenih naroda koje su utemeljene 1992., čiji je središnji cilj bio nadgledanje i učvršćivanje prekida ratnih sukoba u okupiranom dijelu Hrvatske.

71 PHSP: „Proglas HSP-a o sadašnjem predsjedniku Republike“.

72 Ubojstvo stranačkog dopredsjednika Ante Paradžika u Sesvetama, koje su počinili pripadnici hrvatske policije, potreslo je HSP, koji je nakon toga još više radikalizirao svoje djelovanje prema vladajućoj stranci. O ubojstvu Paradžika i njegovu političkom djelovanju vidi: LUČIĆ 2016; VESELINOVIĆ 2015.

73 Smeta li Globusu HSP?. Večernji list, 25. srpnja 1992.
} 
vidljivo je u izbornom istupu Đapića, koji je izjavio da je HDZ, ,izigrala povjerenje svojeg naroda, jer nije htjela znati kako živi mali, obični čovjek, što osjeća hrvatski narod". ${ }^{74}$ Pored toga, Paraga je, govoreći uime naroda, vladajuće povezivao s korupcijskim radnjama i pljačkom naroda. „Kupovali su vile i otvarali privatne račune dok je trebalo kupovati oružje za hrvatske vojnike. To im hrvatski narod nikada neće oprostiti“ “ ${ }^{75} \mathrm{U}$ vezi s kupnjom vila Paraga je eksplicitno prozivao Tuđmana, ali i Savku Dabčević Kučar iz oporbe, smatrajući da je takav luksuz „udarac za milijun Hrvata bez doma“" ${ }^{76}$ Najavljivao se zbog toga obračun s vladajućom elitom: „koliko je sad nama vruće, toliko će još toplije biti njima kad će 2. kolovoza morati napustiti Banske dvore i Sabor, a neki is lisicama na rukama zbog krađa i svega onoga što su dosad radili““. ${ }^{77} \mathrm{U}$ konačnici, Paraga je tijekom izborne kampanje govorio i o tome kako institucije ne djeluju u korist i za narod, već samo za vladajuću elitu. „Suočeni smo s velikim osiromašenjem nacije, s ukidanjem ili marginaliziranjem institucija koje bi jamčile jako, moderno, demokratsko hrvatsko društvo“, obećavajući „,bogati narod, a siromašnu državu“, misleći da bi dolazak HSP-a na vlast „bio renesansa za Hrvatsku“ “ ${ }^{78}$ Riječju, HSP treba vlast „ne radi sebe, nego radi naroda“ ${ }^{79}$ Može se zaključiti da su pravaši u svojim nastupima narod vidjeli kao kolektivno, tj. dobro homogeno tijelo, zanemarujući bilo kakve individualne potrebe, nasuprot kojih je ,pokvarena“ i zla politička elita koja ih je izdala i prodala, naročito tijekom rata. Zbog toga je za HSP vladajuća politička elita bila glavni neprijatelj, dok su „opasni Drugi“ bili (pobunjeni) Srbi koji su narušavali homogenost naroda i države. Riječima Parage: „Tko je kriv za sadašnje stanje? S jedne strane četnici, a s druge hrvatski vrhovnik. Moramo promijeniti vodstvo Hrvatske“" ${ }^{80}$ Vladajuća politička elita na takvo je političko djelovanje HSP-a odgovarala strategijom izolacije, odbacujući mogućnost koaliranja i sukoba, napadajući i optužujući stranku za demagogiju te ,protuhrvatsku politiku“, a njezine prvake, naročito Paragu, prozivali su „,irkusantom“ ${ }^{81}$ Tuđman se tijekom kampanje također kritički osvrtao na HSP, prvenstveno na Paragu, optužujući ga pred onima koji su nosili njegove slike da se družio ne samo s Jugoslavenima već i sa Srbima. „Dok smo se mi borili, on nas je tužio da ubijamo Srbe! Ta tobože pravaška stranka i ti čije ste slike tu izlijepili tužili su nas Helsinkiju, američkom

\footnotetext{
74 Srušit ćemo boljševike. Novi Vjesnik, 26. srpnja 1992.

75 Gdje su Kordun i Banija?. Večernji list, 24. srpnja 1992.

76 Zahtjeva se međunarodna kontrola. Večernji list, 18. srpnja 1992.

77 Srbija mora kapitulirati. Večernji list, 28. srpnja 1992.

78 Ni moja se žena neće voziti u državnom autu. Novi Vjesnik, 11. srpnja 1992.

79 Rat je tek počeo. Večernji list, 14. srpnja 1992.

80 Ne dajemo lažna obećanja. Večernji list, 20. srpnja 1992.

81 Vidi npr. HSP vodi protuhrvatsku politiku. Novi Vjesnik, 24. srpnja 1992.; Paraga - cirkusant. Novi Vjesnik, 29. srpnja 1992.
} 
predsjedniku, da Hrvatska ubija Srbe u Lici. Prema tome, vidi se da su oni u nečijoj službi, u protuhrvatskoj službi“ “.22 Analizirajući odnos Tuđmana i HSP-a tijekom izborne kampanje 1992., može se zaključiti da su i jedni i drugi spominjali Srbe u sukobu kako bi se prikazali što većim zaštitnicima hrvatskog naroda.$^{83}$ Paraga je u svojim nastupima smatrao da govori u interesu naroda kojeg je vladajuća elita izdala i da upravo on izražava njegovu volju. Već se kroz obilježje autoritarnosti utvrdilo da je Paraga neosporno središnja figura u stranci. Tijekom cijelog političkog djelovanja predstavljao se kao „,̌ovjek iz naroda“ i kao osoba koja može spasiti narod i cijelu državu. Nastupao je kao nov, mlad čovjek u politici koji nije imao naslijeđe komunizma, za razliku od stare i velikog dijela nove političke elite, koje je smatrao neprijateljima naroda, pri tome javno prozivajući, primjerice, Tuđmana, njegove najbliže političke suradnike poput predstojnika Ureda za zaštitu ustavnog poretka Josipa Manolića, predsjednika Izvršnog odbora HDZ-a Stjepana Mesića, glavnog državnog odvjetnika Vladimira Šeksa, predsjednika Vlade Franju Gregurića, cijeli HDZ itd. Predstavljao se kao obični Hrvat, religijski i obiteljski čovjek s djecom. Njegovi govori bili su izravni, dinamični i nabijeni emocijama, što je definitivno privlačilo pozornost ljudi jer su njegovi i skupovi cijelog HSP-a bili najposjećeniji 1992. u izbornoj kampanji. Međutim, osvojeno je (samo) pet saborskih mandata. Povijest je kasnije pokazala da se takve kampanje HSP-a s novim vodstvom više neće ponoviti te da mediji neće toliko pozornosti posvetiti stožernoj pravaškoj stranci. Međutim, Paraga je tada nudio jednostavna rješenja za kompleksne probleme, kao što je, primjerice, obrana države, jer je želio prebacivanje rata u Srbiju i slično. Prikazivao se kao vođa i spasitelj naroda osnivanjem i organiziranjem HOS-a, čiji je bio vrhovni zapovjednik. Tako je pokazivao i akcijom da je spreman boriti se i štititi narod. Paraga je zaista imao svoje sljedbenike koji su u njemu vidjeli iznimnog, karizmatskog vođu. Majice s njegovim likom i imenom nosili su tijekom izborne kampanje njegovi tjelohranitelji. U himni HOS-a koja se izvodila u izbornoj kampanji 1992. pjevalo se o Paragi kao o novome poglavniku (vođi), pri čemu se zaklinjalo ustaškim časnicima i poglavniku da će s Paragom ići ako treba i u smrt: „Kunem ti se, Francetiću, Srbiju spalit ću, kunem ti se, moj Bobane, zavit ću ti sve rane. Kunem ti se, Paveliću, još bolji postat ću, uz Paragu i uz HOS, ja do smrti ostat ću!“‘.84

Desni radikalizam tijekom razdoblja lojalne oporbe, 1993. - 1999.

Paragina radikalna kritika vladajuće političke elite, ali i vođenje stranke doveli su do velikog unutarstranačkog raskola 1993., u kojem su nezadovoljnici okupljeni

\footnotetext{
82 Paraga nas je tužio svijetu da ubijamo Srbe. Večernji list, 24. srpnja 1992.

83 VESELINOVIĆ 2016: 83.

84 Himna HOS-a. https://www.youtube.com/watch?v=TqzXImf_86Q (posjet 2. 7. 2018).
} 
oko Ante Đapića i Borisa Kandarea preuzeli HSP, znatno približivši djelovanje stranke vladajućem HDZ-u pretvorivši se u njegova desnog satelita. ${ }^{85}$ Nakon velikog pravaškog raskola pravo u javnosti da zastupa i predstavlja HSP dobio je Đapić. Jesu li i tada u djelovanju HSP-a postojali elementi radikalne desnice prema teorijskom okviru Casa Muddea? Razmotrimo li djelovanje i ideologiju HSP-a od raskola 1993. pa sve do smrti Franje Tuđmana, možemo zaključiti sljedeće. Nativizam je i dalje imao ulogu u politici HSP-a. Odmah nakon raskola Kandare je, govoreći o Paragi, istaknuo da je on i dalje saborski zastupnik HSPa, navodeći standardnu kritiku o autokratskom vođenju stranke i zamjeravanje izjave o progonima Srba, Muslimana, Židova i Albanaca s kojima se ne slaže, iako bi bilo dobro da ima progona Srba. ${ }^{86}$ Iz takve radikalne izjave bilo je vidljivo da Kandare zastupa ideju progona čak i onih Srba koji su bili lojalni hrvatskoj državi. Programatski, pravaši su imali zaoštren stav prema Srbima i Srbiji. U tom smislu, bili su protivnici povratka svih izbjeglih hrvatskih Srba. Suradnja sa Srbijom ne bi bila moguća bez vojnog poraza režima Slobodana Miloševića, preuzimanja odgovornosti za agresiju i isplate ratne odštete.$^{87}$ Riječju, povratak Srba narušavao bi homogenost hrvatske nacije i ugrožavao opstojnost nacionalne države. Pored toga, zastupali su stav da bosansko-hercegovački Srbi ne bi trebali biti jedan od konstitutivnih naroda u BiH zbog ratne agresije. ${ }^{88} \mathrm{U}$ konačnici, Đapić je zalaganje da se izbjeglim Srbima spriječi povratak argumentirao financijskim troškom države. ,Srbi nam ne trebaju, jer njihov povratak Hrvatsku košta milijardu dolara. Hrvatska država neće biti ničija krava muzara kao što to misle komunistički kadrovi“" ${ }^{89}$ Đapićev je stav prema Srbima općenito bio loš i u svojim saborskim nastupima često je tijekom 1990-ih davao ksenofobne izjave poput: „I jedan Srbin u Saboru je previšs“ “ili „Srbi u Hrvatskoj nisu političko, nego ekološko pitanje“ .90 Zaoštrenost HSP-a kada su u pitanju prava nacionalnih manjina vidljiva je i u činjenici da su pravaši bili protiv osnivanja manjinskih stranaka s nacionalnim predznakom, kao i stav da se prava manjina u Hrvatskoj moraju ravnati prema načelu reciprociteta. „Ona dakle ne smiju biti veća od prava kakva ima hrvatski narod u matičnim zemljama tih etničkih i nacionalnih zajednica i manjina".91 Tomu valja dodati da je HSP programatski bio protiv zapošljavanja stranaca u

85 ZAKOŠEK 2002: 44.

86 Pravaši će udružiti hrvatsku desnicu. Vjesnik, 19. rujna 1993.

87 PHSP: Vizija nove Hrvatske.

88 ROHAČEK 2009: 110.

89 Senj: Đapić: Povratak Srba košta milijardu dolara. Večernji list, 21. prosinca 1999.

90 Naše psovke, od konja do alpskog četnika. Jutarnji list, 28. kolovoza 2010. http://www.jutarnji. hr/vijesti/hrvatska/nase-psovke-od-konja-do-alpskog-cetnika/2125380/; Hebrang: Političar ne smije lagati više od 10\%. Slobodna Dalmacija, 16. prosinca 2006. http://arhiv.slobodnadalmacija. $\mathrm{hr} / 20061216 /$ spektar04.asp (posjet 2. 7. 2018).

91 PHSP: Vizija nove Hrvatske. 
Hrvatskoj, kao i to da je zastupao uvjerenje kako stranci ne smiju biti vlasnici zemljišta u Hrvatskoj. ${ }^{92}$ Pravaši su uspostavu ekskluzivne nacionalne države u kontinuitetu htjeli ostvariti načinom vanjske ekskluzivnosti koja podrazumijeva povratak Hrvata izvan granica u matičnu nacionalnu državu. ${ }^{93}$

Autoritarnost je u stranačkom programu i djelovanju imao najznačajniju ulogu. HSP se zalagao za jačanje oružanih snaga i policije, bez kojih Hrvatska ne može biti sigurna zemlja pogodna za razvoj i napredak, zemlja ostvarenja punine nacionalnih interesa hrvatskog naroda. Zatim, stranka je vjerovala da bi strože kazne odvraćale od kriminala te se zalagala za neovisniji pravosudni sustav i njegovo jačanje, kao i za uvođenje predsjedničkog sustava u kojem bi predsjednik države bio i premijer. ${ }^{94}$ Đapić je predsjednički sustav smatrao nužnim, tvrdeći da je Hrvatskoj „potrebna, kao i 1991. godine, čvrsta i sigurna ruka koja će se moći obračunati s kriminalom i nepravilnostima. U protivnom imat ćemo saborsku poziciju gdje će biti trgovina i kompromisi i neće se krenuti u rješavanje problema“. ${ }^{95}$ Zatim, HSP se zalagao za ukidanje pobačaja, pronatalitetnu politiku i jačanje institucije obitelji koje moraju počivati na kršćanskim temeljima, uz čuvanje kulturne baštine i tradicionalnih vrijednosti od amerikanizacije i srbizacije. ${ }^{96}$ Znakovito je da je, prema riječima Tončija Tadića, cijeli politički program HSPa - „Vizija nove Hrvatske“ iz 1996. - programatski bio sličan onome Slobodarske stranke Austrije. ${ }^{97}$ To sigurno nije bilo slučajno jer su spomenuti bili jedni od najuspješnijih radikalno-desnih populističkih stranaka u Europi sa zapaženim izbornim rezultatima. Time je HSP htio pokazati koje su mu stranke bliske i kakvom se strategijom želi koristiti. Tijekom saborskih sjednica 1995. Đapić je otvoreno zagovarao mogućnost uvođenja smrtne kazne za posebne slučajeve protiv osoba koje su dignule pobunu protiv hrvatske države. ${ }^{98}$ Iako je zagovaranje smrtne kazne odlika stranaka radikalne desnice, treba istaknuti da je, prema prvim programskim načelima iz 1990., HSP bio protiv smrtne kazne. ${ }^{99}$ Time je vidljivo da je pod vodstvom Đapića još snažnije radikalizirao svoje djelovanje. Naglašavanje antikomunizma bilo je pravaški kontinuitet, što pokazuje zalaganje za lustraciju. Štoviše, HSP je smatrao da je nakon stvaranja države pobjedom u Do-

\footnotetext{
92 Isto.

93 Isto.

94 Isto.

95 Domovini je potrebna čvrsta i sigurna ruka. Slobodna Dalmacija, 21. prosinca 1999. http:// arhiv.slobodnadalmacija.hr/19991221/novosti2.htm (posjet 2. 7. 2018).

96 Istospolne zajednice u pravnom sustavu. Izvješća Hrvatskog sabora br. 373., 2002: 50-52.

97 Abolicija svih branitelja od 1990. do 1996. moguća je i nužna. Slobodna Dalmacija, 23. veljače 2001.

98 I za oprost treba snage. Večernji list, 1. lipnja 1995.

99 PARAGA I PARADŽIK 1991: 13.
} 
movinskom ratu brzo potrošen nacionalni naboj, nakon čega su na vidjelo izašle već odavno nazočne slabosti hrvatskog društva koje je bilo zatrovano „komunističkim internacionalizmom i bizantsko-balkanskim mentalitetom", naglašavajući da su slabosti „posljedica duboke moralno-etičke krize hrvatskog društva, uzrokovane polustoljetnim komunističkim rušenjem svih tradicijskih i istinskih civilizacijskih vrijednosti““ ${ }^{100}$ Kao „lijek“ i odgovor HSP-a na krizu hrvatskog društva bila je lustracija svih komunističkih dužnosnika i kadrova koji su nastavili svoje djelovanje u samostalnoj hrvatskoj državi. ${ }^{101}$ Nakon provedbe lustracije bilo je potrebno probuditi moralne vrijednosti hrvatskog naroda. To je značilo sustavno promicanje visokih dometa „,bogate hrvatske povijesne baštine, a hrvatske nacionalne simbole poželjno je često isticati, kako bi konačno mogli postati svakodnevnim obilježjima u Domovinskom ratu dokazanog hrvatskog patriotizma“ ${ }^{102}$ Vidljivo je da je time HSP želio građane konstantno podsjećati na hrvatski nacionalni identitet. To se najbolje postizalo medijskim evociranjem povijesnih događaja, proslava obljetnica i vojnih mimohoda, od kojih je najbolji primjer mimohod hrvatskih branitelja u Rijeci, koji je predvodilo i vodstvo HSP-a putem HOS-a. ${ }^{103}$ I u kasnijim pravaškim deklaracijama stvarao se narativ o tome da je osnovni temelj hrvatske suverenosti izgrađen u Domovinskom ratu, „kojega je Vukovarska bitka najčasniji dio i najponosniji simbol, žrtvovanjem branitelja koji su tim činom osigurali svojoj Domovini opstanak a sebi slavu i zasluge koje se ne smiju zaboraviti U skladu s pravednošću i moralom kojim je obranjena Domovina, svaki Hrvat ima dužnost, a član Hrvatske stranke prava i obavezu, ponašati se u skladu s tim moralnim pokladom“. ${ }^{104}$ Alternativni pogled na Domovinski rat HSP, dakle, nije tolerirao, niti je dopuštao kritički pogled. Štoviše, tražila se abolicija svih hrvatskih branitelja od 1990. do 1996. jer je ,suvereno pravo hrvatske države da tretira zbivanja tijekom svog rata i rad svojih oružanih snaga“ ${ }^{105}$ Pravaška ideologija i politika glede Domovinskog rata i stvaranja mita o njemu, ne dopuštajući alternativno viđenje, bile su u skladu s državnim narativom kada je u pitanju Domovinski rat i stvaranje samostalne hrvatske države. ${ }^{106}$ U konačnici, treba istaknuti organizaciju stranke i položaj predsjednika HSP-a koji je, prema Statutu, bio prezidencijalistički. U tom je smislu predsjednik stranke centralizirao moć u svojim rukama uvodeći personalizaciju u političkoj komu-

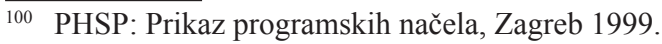

101 Isto.

102 Isto.

103 VESELINOVIĆ 2016: 94-95.

104 PHSP: Vukovarska deklaracija, Vukovar, 18. rujna 2010.

105 Abolicija svih branitelja od 1990. do 1996. moguća je i nužna. Slobodna Dalmacija, 23. veljače 2001.

106 O tome detaljno vidi: JOVIĆ 2017.
} 
nikaciji. Pri tome treba naglasiti da je riječ o personalizaciji kao personifikaciji. Drugim riječima, Đapić je bio u prvom planu, stvarajući imidž neupitne personifikacije hrvatske državotvornosti. Za HSP i Đapića Domovinski rat bio je temelj stvaranja nacionalne države koji se nije smio dovoditi u pitanje. Đapić se može opisati kao autoritaran vođa i zbog načina na koji se nosio s unutarstranačkom oporbom jer se taktikom i eliminacijama lako riješio otvorenih kritičara i unutarnjih protivnika u HSP-u, od Ante Prkačina do Ivana Gabelice, čime je zapravo nastavio kontinuitet Paragina vođenja stranke. ${ }^{107}$ Kada je riječ o populizmu, on je također nazočan u HSP-u, no ne u tolikoj medijskoj mjeri koliko u vrijeme Parage. Tijekom izborne kampanje 1995. objavljena su 24 novinska priloga (po 12 u Vjesniku i Večernjem listu) o HSP-u, od kojih se u Vjesnikovim prilozima pet, a u onima Večernjeg lista dva puta pozivalo na hrvatski narod. Sveukupno sedam puta. U toj je kampanji zabilježeno i jedino sadržajno pojavljivanje nekog predstavnika HSP-a (intervju s Đapićem) na naslovnici Večernjeg lista u povijesti izbornih kampanja stranke. Takvo slabo medijsko praćenje HSP-a u državnim medijima ne iznenađuje s obzirom na to da su oni tijekom izbora 1995. izrazitu prednost davali promociji vladajućeg HDZ-a i Tuđmana. ${ }^{108}$ Još je slabija medijska popraćenost bila tijekom izborne kampanje 1999., kada je objavljeno svega 14 priloga (pet u Vjesniku, devet u Večernjem listu) o izbornoj promidžbi koalicije HSP-HKDU, gdje se svega po jednom u svakim novinama pozivalo na hrvatski narod. Time je vidljivo da je HSP medijima bio sve manje zanimljiv i nije dobivao velik prostor u Vjesniku i Večernjem listu za iznošenje svojih političkih stavova što su 1990-e odmicale kraju. Takav medijski kontinuitet nastavio se i početkom 21. stoljeća. Pravaši su tijekom izbornih kampanja sebe predstavljali braniteljima naroda, međutim, izostala je kritika vladajuće elite, naročito predsjednika Tuđmana. Tako je, primjerice, tijekom cijele izborne kampanje 1995. i 1999. izostao negativan odnos prema HDZ-u. Iako je HSP nakon raskola de facto cijelo vrijeme djelovao kao lojalna oporba za vrijeme vladavine predsjednika Tuđmana i HDZa, treba spomenuti i jedno kratkotrajno, vjerojatno pragmatično odstupanje koje se dogodilo u proljeće 1994. godine. Tom je prilikom zbog unutarstranačkog sukoba i raskola u HDZ-u došlo do izazivanja parlamentarne i političke krize u državi. Disidenti HDZ-a, kao i sve oporbene stranke, uključujući i HSP, bojkotirali su rad Sabora. Međutim, ubrzo je upravo HSP bio prva oporbena stranka koja se vratila i sudjelovala u radu Sabora, pokazujući svoju oporbenu lojalnost vladajućoj eliti. ${ }^{109}$ Umjesto toga, pravaši su imali tri vrste neprijatelja: neprijatelja izvan države i nacije vidjeli su u Međunarodnom kaznenom sudu za bivšu Jugo-

107 VESELINOVIĆ 2018: 146-191.

108 BARANOVIĆ 1995.

109 VESELINOVIĆ 2018: 146-191. 
slaviju (MKSJ); neprijatelj izvan nacije, a unutar države, bila je srpska nacionalna manjina; neprijatelji unutar nacije i države bili su (reformirani) komunisti. ${ }^{110}$ Populizmu HSP-a treba dodati i pozivanje na provedbu referenduma kada je u pitanju povratak izbjeglih, između ostalog i onih koji su bili sudionici oružane pobune. Referendum (članova stranke, nap. a.) bio je ugrađen i u Statut HSP-a, a odnosio se na eventualnu odluku o prestanku političkog djelovanja stranke. ${ }^{111}$ S obzirom na navedeno, može se zaključiti da je u ovom razdoblju bila riječ o krnjem populizmu iz razloga što je izostala kritika vladajuće političke elite. Medijska marginalizacija u dvama izbornim ciklusima potvrdila se i uz izbornim rezultatima jer je HSP na izborima 1995. i 2000. osvajao po četiri saborska mandata.

Desni radikalizam na prijelazu stoljeća, 2000. - 2003.

U Hrvatskoj je na prijelazu iz 20. u 21. stoljeće na prvim kritičnim izborima došlo do promjene vlasti koju je preuzela šestočlana lijeva koalicija, predvođena Socijaldemokratskom partijom (SDP) na čelu s Ivicom Račanom koji je postao novi premijer, dok je Stjepan Mesić iz Hrvatske narodne stranke (HNS) izabran za drugoga hrvatskoga predsjednika. Razmotrimo li rekonstrukciju djelovanja HSP-a za vrijeme vladavine lijeve koalicije, možemo zaključiti sljedeće. Nativizam, kao prvi element teorijskog okvira radikalne desnice Casa Muddea, bio je zastupljen u politici HSP-a. U prvom redu, pravaški je javni diskurs bio neprijateljski nastrojen prema predstavnicima srpske političke elite u Hrvatskoj. U tom se smislu kritizirala Samostalna demokratska srpska stranka (SDSS) zato što se, prema pravaškom uvjerenju, nije očitovala kada je u pitanju bila velikosrpska agresivna politika. Međutim, Đapić je općenito bio kritičan prema nacionalnim manjinama, smatrajući da su spomenuti 2003. postali odlučujući faktor pri etabliranju i provođenju vlasti. ${ }^{12}$ Tome valja dodati da je 2002. prilikom donošenja Ustavnog zakona o pravima nacionalnih manjina u Saboru jedino Klub zastupnika HSP-HKDU bio protiv izglasavanja navedenog zakona. Treba istaknuti da je početkom 2000. Đapić napravio i neke pozitivne, ali kratkotrajne - vjerojatno iz pragmatičnih razloga (HSP je tada imao udio u lokalnoj vlasti, nap. a.) - pomake u odnosu s predstavnicima tadašnje srpske političke elite ručajući s Milanom Đukićem, predsjednikom Srpske narodne stranke, u Donjem Lapcu. ${ }^{113}$ Tom je prilikom Đapić izjavio: „Hrvati

110 Isto.

111 PHSP: Statut Hrvatske stranke prava, Zagreb, 24. veljače 1996.

112 Puhovski: Sjajan potez, Đapić: Iskorak iz protokola. Slobodna Dalmacija, 8. siječnja 2004. http://arhiv.slobodnadalmacija.hr/20040108/novosti06.asp (posjet 2. 7. 2018).

113 Milan Đukić na čelu Donjeg Lapca. Slobodna Dalmacija, 21. rujna 2000. http://arhiv.slobodnadalmacija.hr/20000921/novosti2.htm, Đapić s Đukićem jeo janjetinu i pio „rakijicu“. Večernji list, 21. rujna 2000. http://www.hsp1861.hr/vijesti/200921fs.htm (posjet 2. 7. 2018). 
i Srbi u Donjem Lapcu mogu živjeti jedni s drugima, a novi načelnik općine Đukić imat će moju apsolutnu potporu u svim svojim planovima jer je sada Donji Lapac, što se tiče uvjeta života, zona sumraka“. ${ }^{114}$ Takva potpora bila je kratkog vijeka jer je Đukić dolaskom na vlast preko Općinskog vijeća izmijenio nazive ulica i trgova u Donjem Lapcu, što je izazvalo negativnu reakciju HSP-a i Đapića, koji je izjavio kako se boji „da ćemo slične probleme imati i u drugim mjestima na područjima oslobođenim 'Olujom', gdje je očit masovan povratak Srba“.${ }^{115} \mathrm{Od} 18$ naziva, preimenovano je njih 14 , a pravaši su najvjerojatnije najviše bili revoltirani preimenovanjem naziva koji su imali istaknutu vezu s hrvatskim državotvornim i vojnim identitetom, poput Ante Starčevića, Franje Tuđmana, hrvatskih branitelja ili 9. gardijske brigade „Vukovi“, te imenovanjem naziva povezanih sa srpskim identitetom, poput Vuka Stefanovića Karadžića, i antifašizmom, poput Josipa Broza Tita ili Stojana Matića. Pri tome su za takvu odluku u HSP-u najviše krivili prijašnju HDZ-ovu vlast „koja je omogućila da se vrati i naseli tko god želi, pa i oni koji ovdje prije nikada nisu živjeli. U Lapac su došli Srbi iz Bosne i Hercegovine te iz Srbije i ukupno ih s povratnicima ima oko tri tisuće. U Općinskom vijeću imaju većinu i rade što hoće, pa tako bez muke mijenjaju i imena ulica“". ${ }^{116}$ U konačnici, Đapić se protivio ulaganju hrvatskih tajkuna u Srbiju. „Zapošljavaju tako srpsku radnu snagu, umjesto da ulažu u hrvatska nerazvijena područja“". ${ }^{117}$ Dolaskom na vlast lijeva je koalicija napravila iskorake i u pravima seksualnih manjina. Tako je 2002. u Zagrebu održana prva gay povorka koju je organizirala udruga Iskorak. HSP na tako nešto nije gledao s odobravanjem, smatrajući da se toj temi pridaje velika pozornost. „Po svojem habitusu nismo skloni neoliberalnim pretjerivanjima, a takvim smatramo povorku homoseksualaca. Mislim da homoseksualnost nije tema koja zaslužuje ovakvo nacionalno uzdizanje, kao što se uzdiže u posljednje vrijeme. I ne mogu shvatiti zašto takvi liberali, primjerice, žele brak, koji je u svojoj suštini konzervativna zajednica. Nije li paradoks što se zaklinju u civilno društvo, kojem je najbitnija jedinka, a žele brak“. ${ }^{118}$ U skladu s time, Klub zastupnika HSP-HKDU bio je protiv donošenja Vladina Zakona o istospolnim zajednicama te je u saborskoj raspravi Anto Kovačević tvrdio da se predloženim Zakonom ne radi „o ljudskim pravima, nego o projektu uništavanja temelja hrvatske obitelji, gazi se po interesima ipak većine hrvatskog društva,

114 „Četnik“ i „ustaša“ u koaliciji. AIM, 23. studenog 2000. http://www.aimpress.ch/dyn/pubs/ archive/data/200009/00923-003-pubs-zag.htm (posjet 2. 7. 2018).

115 Iz naziva ulica izbačeni Starčević, hrvatski branitelji i 4. gardijska. Večernji list, 28. veljače 2001. http://www.hsp1861.hr/vijesti/010228ik.htm (posjet 2. 7. 2018).

116 Isto.

117 Krupni kapitalisti plaćat će „danak“ tri do pet posto. Večernji list, 17. studenog 2003.

118 Sto zaštitara čuvat će homoseksualce. Večernji list, 26. lipnja 2002. https://www.vecernji.hr/ vijesti/sto-zastitara-cuvat-ce-homoseksualce-718500 (posjet 2. 7. 2018). 
jer kada bi o ovim zakonima opasnim za budućnost nacije i razvoja humanog i zdravog čovjeka pitali javnost i proveli referendum, vjerujte, dobili bismo $98 \%$ građana protiv donošenja ovakvog zakona“, naglašavajući da su istospolne zajednice „suprotne kršćanskoj civilizaciji“. ${ }^{119}$

Anto Đapić je u stranci imao potpuni prezidencijalistički položaj. U tom je smislu imao potpunu moć u odlučivanju, posve minimalizirajući ulogu članstva i središnjih stranačkih tijela, uz kontinuiran nastavak personalizacije u političkoj komunikaciji. HSP se zalagao za raspisivanje referenduma o temi prava stranaca na posjedovanje nekretnina te o Sporazumu o stabilizaciji i pridruživanju s EU koji nije bio prihvaćen. ${ }^{120}$ Koliko je pravašima instrument referenduma bitan, pokazala je i izmjena Ustava koju je 2000. pokrenula vladajuća lijeva koalicija, što je HSP podržao jer je njezin amandman o mogućnosti da 10 posto građana može zatražiti referendum oko svih važnih pitanja bio prihvaćen.To dovodi do zaključka da je populizam i dalje bio nazočan u suvremenoj pravaškoj ideologiji. Tijekom izborne kampanje 2003. objavljeno je 25 novinskih priloga o HSP-u (19 u Vjesniku i 6 u Večernjem listu), od kojih se u Vjesnikovim prilozima devet, a u onima Večernjeg lista pet puta pozivalo na hrvatski narod. Sveukupno 14 puta. Programatski, pravaši su isticali da oni nisu ,gore“, nego „dolje“, želeći pri tome služiti narodu i govoriti u njegovo ime. „Mi osluškujemo narod i pokazali smo da znamo što boli hrvatskog čovjeka““. ${ }^{121}$ Uz kritiziranje vladajuće političke elite koju je predvodio SDP, naglašavali su da ne snose odgovornost za stanje u državi jer su uvijek bili oporba, sebe predstavljali braniteljima naroda. Đapić je tako tijekom izborne kampanje naglašavao da ,nisu sve stranke jednake. Mi nikada nikomu nismo gurnuli ruku u džep. I dalje ćemo štititi hrvatski narod i interese, a za one koji su privatizacijom pljačkali tijekom rata, neće biti zastare". ${ }^{122} \mathrm{U}$ konačnici, Đapić je prikazivao HSP kao jedinu političku alternativu koja nije pljačkala narod. „HSP je alternativa općoj političkoj situaciji u kojoj su svi, osim nas, kompromitirani kroz pljačku hrvatskog naroda“". ${ }^{123}$ Negativno referiranje na vladajuću političku elitu zabilježeno je tijekom trajanja izborne promidžbe. $\mathrm{Na}$ udaru je osobito bila Vesna Pusić iz HNS-a koja je smatrala da bi glasovanje za desne stranke bilo ravno izdaji, što je izazvalo revolt pravaša. „Ona (Pusić, nap. a.) je izdala Hrvatsku jer njena stranka i vladajuća koalicija nisu ispunili izborna obećanja“, uz dodatak da „HSP nije bio zadovoljan rezultatima izbora 3. siječnja 2000., ali narod nismo optuživali za izdaju“. ${ }^{124}$ Pored toga, vladajuću političku

\footnotetext{
119 Istospolne zajednice u pravnom sustavu. Izvješća Hrvatskog sabora br. 373., 2002: 50-52.

120 VESELINOVIĆ 2018: 192-230.

121 HSP: Vlada se neće moći formirati bez nas. Večernji list, 15. studenog 2003.

122 HSP: Za ratne profitere nema zastare. Večernji list, 17. studenog 2003.

123 Đapić: Spriječit ćemo podjelu Hrvatske. Vjesnik, 12. studenog 2003.

124 HSP: Pusić izdala Hrvatsku, jer HNS nije ispunio obećano. Vjesnik, 4. studenog 2003.
} 
elitu prozivalo se da se ponaša poput pijanog milijardera. ${ }^{125}$ Zbog toga se može smatrati da se populizam pravaša temeljio i na kritici kartelizacije političkog života velikih stranaka. „Država i javna uprava postale su same sebi svrha. Najgore je što se šljam iz prošle uprave udružio sa šljamom iz nove uprave. (...) Da se dobro gospodarilo, moglo se uštedjeti pet do sedam posto proračunskog novca“. ${ }^{126}$ Takva poruka pokazuje da su i stara i nova vlast jednake jer troše državna financijska sredstva za sebe, a ne za potrebe naroda. Izborna kampanja HSP-a pokazala je još jednu novost kada su u pitanju političke elite. U njoj je od strane pojedinih pravaša stavljen znak jednakosti između dviju najvećih stranaka, HDZ-a i SDP-a. Tako je, primjerice, Miroslav Rožić isticao da Hrvatska nije bila pravna i pravedna država ni „za vrijeme HDZ-a, ali ni za vrijeme SDP-a i koalicije“. ${ }^{127}$ Međutim, nekakav izrazitiji negativan odnos prema HDZ-u ipak je izostao jer su pravaši očekivali da će nakon izbora postati dio njihove vladajuće većine s obzirom na osvojenih osam saborskih mandata, što je bio najbolji izborni rezultat HSP-a u novijoj nacionalnoj i pravaškoj povijesti. „Opasni Drugi“ u tom periodu bile su nacionalne i seksualne manjine te MKSJ koji „kriminalizira“ Domovinski rat. Dolaskom na vlast, lijeva je koalicija odmah izrazila spremnost na suradnju s MKSJ-om, što je naišlo na snažan otpor HSP-a, koji je sudjelovao u prosvjedima kojima se željelo ,zaštititi“ Domovinski rat i njegove vrijednosti. Ekstremna desnica je tijekom 2000. počela pripremati, prema pisanju Ive Goldsteina, hrvatsku varijantu „događanja naroda“, „što je uključivalo blokadu cesta, skupove na kojima se pronosio govor mržnje, sve do pozivanje na rušenje ustavnog poretka“. ${ }^{128}$ Možemo kazati da takva usporedba ipak nije u potpunosti na mjestu jer su „događanje naroda" u Srbiji organizirali tamošnji pripadnici ili dijelovi vlasti, dok se u Hrvatskoj radilo o oporbi. Prema Ivi Goldsteinu, počelo je u rujnu 2000., kada je 12 hrvatskih generala - što djelatnih, što umirovljenih - napisalo otvoreno pismo javnosti u kojem su pozvali najodgovornije osobe i ustanove države, a posebice medije, da se odupru negativističkom i neistinitom prikazivanju Domovinskoga rata. Predsjednik Stjepan Mesić to je shvatio kao upletanje vojske u politiku s jasno iskazanim pučističkim namjerama te je bez oklijevanja djelatne generale umirovio. Taj Mesićev potez bio je, prema Ivi Goldsteinu, ,jedan od ključnih u razvoju hrvatske demokracije, jer je time de facto depolitizirana vojska“ “. ${ }^{129} \mathrm{~S}$ druge strane, pismo hrvatskih generala dobilo je punu potporu HSP-a. Đapić je smatrao kako je tadašnja vlast pokušavala prikazati branitelje „kao ekstremiste i razbijače demokracije, a konačni je cilj takve politike uvođenje strahovlade kako bi se

\footnotetext{
125 HSP: Vlast se ponaša kao pijani milijarder. Vjesnik, 20. studenog 2003.

126 Isto.

127 Rožić: HSP-ovu listu predvode stručni i moralni ljudi. Vjesnik, 19. studenog 2003.

128 GOLDSTEIN 2011: 165-166.

129 Isto: 164.
} 
Hrvatska lakše odvela pod skute zapadnog Balkana" te je tražio izvanredne izbore jer se Vlada Ivice Račana pokazala nekompetentnom za rješavanje nagomilanih problema na svim područjima. ${ }^{130}$ Komentirajući umirovljenje hrvatskih generala, Đapić je izjavio da postoji latinska izreka koja kaže: „Koga Bog želi uništiti, učini ga ludim. " ${ }^{131}$ Pismo hrvatskih generala dobilo je i potporu Saveza udruga dragovoljaca HOS-a. ${ }^{132}$ Međutim, i prije rujna 2000., koji spominje Ivo Goldstein, HSP je najavljivao prosvjede desnice jer su držali da vlast pokušava ugroziti temelje Domovinskog rata. HSP je otvoreno najavio građanski neposluh, ali cilj toga neposluha nije trebala biti „destabilizacija Hrvatske, nego destabilizacija Vlade“, što je svrha i zadaća svake oporbene političke stranke, isticao je Đapić. ${ }^{133}$ Sve je započelo u Vukovaru, 30. svibnja 2000., na Dan državnosti, kada je pred oko dvije tisuće ljudi organiziran skup podrške zaštiti vrijednostima Domovinskog rata koji je organizirao SUDHOS, čiji je predsjednik ujedno bio i predsjednik Glavnog stana HSP-a te zastupnik u Županijskom domu Sabora Velimir Kvesić. U svom je govoru potonji istaknuo da vlast želi pobjedu u Domovinskom ratu pretvoriti u poraz i da donosi antihrvatske zakone kojima hrvatske Srbe stavlja u povoljniji položaj od hrvatskih povratnika. Naglasio je i da Ivica Račan zove Srbe u Vukovar jer u njima vidi dio svog biračkog tijela. ${ }^{134}$ Govor je održao i Đapić. U njemu je odbacivao da je u Hrvatskoj bilo ratnih zločina počinjenih od strane hrvatskih boraca i hrvatskog naroda te da svi koji tvrde drugačije udaraju na žrtve Ovčare. Nadalje, protusrpska retorika i govor mržnje naglašeni su u prijetećim riječima: „može Srbima u Vukovaru i ova i ona vlast donijeti stotinu zakona, ali jednom ćemo i mi doći na vlast, a onda jao njima“. ${ }^{135}$

Vraćanje izvorima desnog radikalizma, 2004. - 2015.

Lijeva koalicija bila je na vlasti samo jedan mandat. To je dovelo do (ponovnog) dolaska na vlast HDZ-a u dvama mandatima. Razmotrimo li rekonstrukciju djelovanja HSP-a od 2004. do 2011., možemo zaključiti sljedeće. Nativizam je imao značajnu ulogu u njegovoj politici. U prvom redu, pravaški je javni diskurs i dalje bio neprijateljski nastrojen prema predstavnicima srpske političke elite u Hrvatskoj. Konkretno, to se odnosilo na SDSS, koji ,provodi politiku nacionalne segregacije“. ${ }^{136}$ Može se smatrati da je u tom razdoblju postojalo nekoliko razloga

\footnotetext{
130 Arhiv HRT, 28. rujna 2000. http://www.hrt.hr/arhiv/2000/09/28/ (posjet 29. 12. 2015).

131 Arhiv HRT, 29. rujna 2000. http://www.hrt.hr/arhiv/2000/09/29/ (posjet 29. 12. 2015).

132 Isto.

133 Arhiv HRT, 11. svibnja 2000. http://www.hrt.hr/arhiv/2000/05/11/ (posjet 29. 12. 2015).

134 Kvesić: Račan zove Srbe u Vukovar jer su mu oni birači. Jutarnji list, 31. svibnja 2000.

135 Isto.

13620 glavnih pitanja za 7 glavnih suparnika. Večernji list, 2. prosinca 2011.
} 
pravaške radikalizacije prema predstavnicima SDSS-a. Prvi je bio taj što su pravaši smatrali da SDSS stvara infrastrukturu i pravni okvir za novu SAO Krajinu. Kao argument navodili su „Prijedlog zakona o registru vijeća i koordinacija nacionalnih manjina“" koji definira da se u registar unose i drugi oblici udruga nacionalnih manjina koji se osnivaju sukladno s međunarodnim ugovorima, što u prijevodu „znači da je navedeni, naoko bezazlen zakon, uvod u stvaranje pravnog okvira za novu SAO Krajinu jer će tom vijeću pristupiti svi načelnici općina sa srpskom većinom, koji će voditi srpsku politiku, a koja će dovesti do postavljanja političkih zahtjeva Hrvatskoj i prijetnjama balvan revolucijom“. ${ }^{137}$ Zatim, pravaši su smatrali da su ustavnim promjenama Srbi u Hrvatskoj stekli poseban status. Uvedene su četiri kategorije državljana. U prvoj su oni koji imaju dvostruko pravo glasa i zajamčena tri zastupnika u Saboru. U drugoj su ostale nacionalne manjine koje imaju dvostruko pravo glasa bez zajamčenog broja zastupnika. Treća su Hrvati, „a četvrta hrvatska dijaspora koja će morati stajati danima u redu kako bi došla u priliku glasovati“. Prema pravašima, takvim posebnim statusom Srbi žele nadograđivati politiku ,podijeljenog suvereniteta između hrvatskog i srpskog naroda“, a to služi kao podloga za političku autonomiju i, u konačnici, zahtjev za odcijepljenje dijelova Hrvatske. ${ }^{138}$ Pravaši su naposljetku tražili da se ukine financiranje iz državnog proračuna srpskog tjednika Novosti koji izdaje Srpsko narodno vijeće, čiji je predsjednik Milorad Pupovac ujedno i potpredsjednik SDSS-a. Kao argument navodili su jednu naslovnicu s fotografijom dvaju hrvatskih MIG-ova i velikim naslovom „Obadva, obadva su pala!“ (nap. a.), smatrajući je provokacijom i vrijeđanjem hrvatskih državljana te iskazom neprihvaćanja hrvatske države. Riječju, pravaši su držali da, s jedne strane, politika SDSS-a vodi prema novim južnoslavenskim integracijama ili njihovoj političkoj autonomiji u Hrvatskoj, dok, s druge, provocira i vrijeđa hrvatske državljane navedenim naslovnicama. ${ }^{139}$ Treba istaknuti da je tijekom 2005. Anto Đapić ponovno napravio i neke pozitivne, ali opet kratkotrajne, vjerojatno iz pragmatičnih razloga (HSP je tada prolazio transformaciju želeći postati relevantan akter za sudjelovanje u izvršnoj vlasti; prikazujući se kao proeuropska stranka koja slijedi politiku Europske pučke stranke, napravljen je odmak od ustašonostalgije; Đapić je bio i gradonačelnik Osijeka, nap. a.) pomake u odnosu prema srpskoj manjini tako što je posjetio Srpsku pravoslavnu crkvu u Osijeku te se zalagao za zbrinjavanje izbjeglih osječkih Srba. ${ }^{140} \mathrm{U}$ samoj stranci došlo je do promjena tako što je 2009. za novog predsjednika HSP-a izabran

\footnotetext{
137 Šef HSP-a Srb: SDSS želi stvoriti novu SAO Krajinu!. Jutarnji list, 6. listopada 2010. http:// www.jutarnji.hr/hsp--danijel-srb--sdss-zeli-stvoriti-novu-sao-krajinu-/892879/; Srb: Politika SDSS-a stvara pravni okvir za novu SAO Krajinu. Večernji list, 6. listopada 2010. http://www. vecernji.hr/hrvatska/srb-politika-sdss-a-stvara-pravni-okvir-za-novu-sao-krajinu-199978 (posjet 2. 7. 2018).

138 Isto.

139 Isto.
} 
Daniel Srb. I pod njegovim vodstvom zabilježeni su ksenofobni iskazi. Tako je on izjavio da bi se suprotstavio „svome djetetu ako bi ono željelo stupiti u brak s osobom srpske nacionalnosti“, dok je na homoseksualnost gledao kao na oblik devijantnog ponašanja. ${ }^{141} \mathrm{U}$ skladu s time, uoči desetog zagrebačkog gay pridea HSP je izdao priopćenje za javnost u kojem se pozivalo građane da se sudionicima povorke uskrati pozornost. Poziv je posebno upućen roditeljima koje su zamolili „da u periodu održavanja povorke sklone svoju djecu s mjesta događanja te da im onemoguće gledanje ovog kršenja tradicionalnih hrvatskih kršćanskih i moralnih vrijednosti. HSP ima jasan stav o građanskim pravima, te se slaže da svi trebaju imati jednaka prava pa tako i pravo na šetnju ulicama grada, no isto tako se zalaže za to da manjine ne smiju svojim ponašanjem, stavovima i akcijama ucjenjivati i terorizirati većinu. Hrvatska je kršćanska zemlja izgrađena na tradicionalnim vrijednostima koje se sastoje od vjere u Boga, ljubavi prema Domovini i zajednice obitelji. Obitelji koja je zakonom određena kao zajednica između muškarca i žene a koju neki svojim postupcima žele kao takvu uništiti. Kažimo stop uništavanju Hrvatske, zemlje istinskih vrijednosti““. ${ }^{142}$ Time je vidljivo da pravaši smatraju kako i seksualne manjine svojim istupima ugrožavaju opstojnost hrvatske države i njezin identitet. Unatoč radikalnoj kritici srpske političke elite u Hrvatskoj, bilo je i pozitivnih primjera u odnosima HSP-a prema srpskoj manjini u Hrvatskoj. Tako je sisački HSP predložio da Nagradu grada dobije Petar Olujić, paroh Srpske pravoslavne crkve u Sisku, što je u konačnici i jednoglasno prihvaćeno. Dopredsjednik HSP-a Veljko Novak argumentirao je pravaški prijedlog sljedećim riječima: „Ne vidim opravdanja za čuđenje što smo mi sisački pravaši predložili protu Olujića za Nagradu grada Siska. On je ugledni građanin ovoga grada, čovjek kojeg u Sisku svi dobro poznaju, i to samo po dobru. Ostao je u Sisku i u najtežim vremenima Domovinskog rata, a zbog svojih stavova i opredijeljenosti za Sisak i Hrvatsku kao svoju domovinu, imao je problema među nekim od jastrebova u svojem narodu. No, on se nije dao pokolebati, ostao je uporan u širenju dobrih odnosa među ljudima različitih nacionalnosti i različitih vjera. To što je gospodin Olujić pravoslavni svećenik, što je on Srbin po nacionalnosti, to nama članovima HSP-a u Sisku nije njegov minus. On je prije svega veliki humanist i dobar čovjek“ “. ${ }^{143}$

140 VESELINOVIĆ 2018: 207-219.

${ }_{141}$ Nema braka sa Srbinom. Slobodna Dalmacija, 30. ožujka 2010. http://www.slobodnadalmacija. $\mathrm{hr} /$ novosti/hrvatska/clanak/id/93948/nema-braka-sa-srbinom-zoran-pusic-hsp-ovca-srba-trebakazniti-zbog-mrznje-prema-srbima (posjet 2. 7. 2018).

142 Zagrebački HSP: „Uskratite paradi pažnju! Roditelji, sklonite svoju djecu da ne gledaju kršenje morala“. Index.hr, 17. lipnja 2011. http://www.index.hr/vijesti/clanak/zagrebacki-hsp-uskratiteparadi-paznju-roditelji-sklonite-svoju-djecu-da-ne-gledaju-krsenje-morala/557158.aspx (posjet 2. 7. 2018).

143 Paroh Petar Olujić: Hvala HSP-ovcima na Nagradi grada; Novak: To što je Srbin nije mu minus. Slobodna Dalmacija, 7. lipnja 2011. http://www.slobodnadalmacija.hr/Hrvatska/tabid/66/ articleType/ArticleView/articleId/140042/Default.aspx (posjet 2. 7. 2018). 
Populizam je također bio nazočan u djelovanju HSP-a. Međutim, treba istaknuti da ta stranka tijekom trajanje izborne promidžbe za Sabor 2007. i 2011. nije dobila velik prostor u Vjesniku i Večernjem listu za iznošenje svojih političkih stavova. Tako je, primjerice, tijekom izborne promidžbe 2011. u objema tiskovinama objavljen po jedan prilog o HSP-u, točnije, intervju s predsjednikom stranke Danielom Srbom. Slično je bilo i tijekom izborne kampanje 2007. i u drugim tiskanim medijima, stoga možemo govoriti o izrazito velikoj medijskoj bipolarizaciji stranačko-političkog sustava s naglaskom na HDZ i SDP. ${ }^{144}$ Prvaci HSP-a sebe su proglašavali jedinim pravim demokratima i iskazom prave narodne volje. Oni su ti koji predstavljaju narod, nasuprot „pokvarene“ elite. „Dva politička blizanca ne mogu donijeti promjene koje su Hrvatskoj potrebne, ali mi smo nešto sasvim drugo. Mi možemo, hoćemo i moramo jer mi smo korijeni, mi smo budućnost“ “ ${ }^{145}$ Za pravaše su elitu predstavljale prvenstveno etablirane stranke HDZ i SDP, što je pokazatelj generalizacije stava prema najvećim strankama koje su vodile državu. To je pogotovo bilo vidljivo u izbornim kampanjama 2007. i 2011., kada su od strane HSP-a i HDZ i SDP kao nositelji političke elite proglašeni „sijamskim blizancima" koji su izdali hrvatske nacionalne interese. To pokazuje i vizualna komunikacija HSP-a izbornim plakatom u kojem je politika SDP-a prozvana ,„supljom“, a politika HDZ-a „praznom“. ${ }^{146}$ Štoviše, HSP je izričito smatrao da elite nisu napravile rez s komunističkom prošlošću, da se u prvima dvama desetljećima hrvatske samostalnosti ništa značajno nije promijenilo te da su stare elite zapravo uspjele sačuvati svoju moć i položaje. „Politički sijamski blizanci u sprezi s ostacima bivšeg sustava i kontroliranim medijima već sedam godina obmanjuju i ponižavaju Hrvate. Njihova opsjednutost Europskom unijom u nedostatku vlastitih programa i autonomne politike izaziva u narodu gubitak vjere u vlastite mogućnosti““. ${ }^{147}$ Vladajuća politička stranka na čelu s Ivom Sanaderom tijekom izborne kampanje 2007. na takvo je političko djelovanje HSP-a odgovarala odbacivanjem mogućnosti koaliranja i sukoba te napadanjem pravašâ da je glas za njih glas za SDP. Tom je prilikom Sanader objašnjavao: „Pa, neću valjda trpjeti da on (Đapić nap. a.) govori kako su HDZ i SDP sijamski blizanci“ ${ }^{148}$ Time su se pravaši vratili svojoj kritici

144 BALABANIĆ I MUSTAPIĆ 2008.

145 Đapić: SDP i HDZ su sijamski blizanci jednaki na vlasti. Jutarnji list, 9. prosinca 2006. https:// www.jutarnji.hr/arhiva/dapic-sdp-i-hdz-su-sijamski-blizanci-jednaki-na-vlasti/3245207/ (posjet 2. 7. 2018).

146 TURKOVIĆ 2009: 129.

147 Đapić: SDP i HDZ su sijamski blizanci jednaki na vlasti. Jutarnji list, 9. prosinca 2006. https:// www.jutarnji.hr/arhiva/dapic-sdp-i-hdz-su-sijamski-blizanci-jednaki-na-vlasti/3245207/ (posjet 2. 7. 2018).

148 Sanader se bori za svoje, a Đapić za njegove birače. Večernji list, 19. rujna 2007. https://www. vecernji.hr/vijesti/sanader-se-bori-za-svoje-a-djapic-za-njegove-birace-834439 (posjet 2. 7. 2018). 
koja je bila nazočna na početku 1990-ih. „Pokvarena“ i „korumpirana“ politička elita identificirana je, dakle, u HDZ-u i SDP-u te predsjedniku Stjepanu Mesiću, koji je etiketiran kao „kum tih sijamskih blizanaca i njihov glasnogovornik ${ }^{\text {“149, }}$ dok su „opasni Drugi“ identificirani u „,segregacijskom“ SDSS-u, „devijatnim“ homoseksualcima, MKSJ-u, koji „kriminalizira“ Domovinski rat, te EU-u kojim se „gubi“ državni suverenitet. U konačnici, populizmu HSP-a treba dodati i pozivanje na provedbu referenduma podnošenjem peticija kao oblicima izravne demokracije, poput peticije HSP-a protiv uvođenja ćiriličnog pisma u Vukovaru, peticije za rješavanje graničnog spora sa Slovenijom pred Međunarodnim sudom pravde u Haagu ili, pak, peticije za zaštitu hrvatskog identiteta i suvereniteta povodom prvostupanjske presude MKSJ-a generalima Anti Gotovini i Mladenu Markaču, čime su pravaši željeli da građani izravno sudjeluju u politici i političkom odlučivanju i tako izražavaju vlastitu volju. Autoritarnost je u stranačkom djelovanju također imala ulogu. Godine 2008. Đapić je pokrenuo raspravu o strožem kažnjavanju osuđenih pedofila i silovatelja, predlažući da ih Hrvatska, poput Poljske, kemijski kastrira. Međutim, tako nešto nije dobilo podršku vladajuće elite, a struka je takvu ideju odbacila, smatrajući je ekstremnom i ne potpuno učinkovitom. ${ }^{150}$ Općenito gledajući, tijekom izborne promidžbe 2011. HSP je potvrdio da su mu ideološki srodne stranke iz radikalno-desne populističke obitelji kada je na pitanje koja od europskih stranaka izaziva najviše poštovanja kod njih odgovorila francuska Nacionalna fronta. ${ }^{151}$ Kada je riječ o autoritarnosti u organizaciji stranke, ona je i dalje bila nazočna u kontinuitetu kroz prezidencijalizam Ante Đapića. Tek je dolaskom D. Srba unutarstranačka demokracija počela ulaziti u stranku, što se pokazalo tijekom izbora za predsjednika HSP-a 2009. godine. Unatoč tome, to nije značilo da će Đapićev utjecaj biti smanjen, s obzirom na činjenicu da je i dalje sudjelovao u središnjim stranačkim tijelima. Gubitkom parlamentarnog statusa 2011., HSP je prestao biti dijelom hrvatskoga stranačkog sustava, djelujući na marginama političkog života. To nije utjecalo na stranačku ideologiju, a kasniji događaji poput, primjerice, migracijske krize u Hrvatskoj iz 2015. pokazali su izrazitu sklonost pravaša za antiimigrantske stavove, što je još jedna odlika u ideologiji stranaka radikalne desnice. Tom je prilikom D. Srb tražio od vladajućih podizanje zida na granici sa Srbijom kako bi se spriječio ulazak imigranata u

149 Đapić u Splitu pozvao HSP-ovce na opću mobilizaciju. Večernji list, 27. listopada 2007. https:// www.vecernji.hr/vijesti/djapic-u-splitu-pozvao-hsp-ovce-na-opcu-mobilizaciju-835537 (posjet 2. 7. 2018).

150 Kastracija, kazna i za hrvatske pedofile?. Jutarnji list, 5. listopada 2008. https://www.jutarnji. hr/arhiva/kastracija-kazna-i-za-hrvatske-pedofile/3903105/; Vruća tema predsjedničkih izbora Je li rješenje za pedofile kemijska kastracija?. Jutarnji list, 22. studenog 2014. https://www. jutarnji.hr/vijesti/hrvatska/vruca-tema-predsjednickih-izbora-je-li-rjesenje-za-pedofile-kemijska-kastracija/589021/ (posjet 2. 7. 2018).

15120 glavnih pitanja za 7 glavnih suparnika. Večernji list, 2. prosinca 2011. 
državu. ${ }^{152}$ HSP je tako i u imigrantima koji su u pretežnoj mjeri islamske vjeroispovijesti vidio „opasne Druge“ koji narušavaju homogenost nacionalne države i njezin identitet te kršćanski identitet kako Hrvatske tako i Europe. U svojim su priopćenjima otvoreno iskazivali strah od islamizacije Hrvatske koja bi zbog muslimanskog nataliteta mogla postati „Islamska Republika Croatistan“. „Već smo pisali koliko je potrebno islamskih imigranata za islamizaciju Hrvatske u relativno kratkom roku, samo 30000 obitelji na 50 godina prema natalitetu od 8,1 djeteta po obitelji i Hrvati će u Hrvatskoj biti manjina“. ${ }^{153}$ Zapravo, HSP je i općenito iskazivao strah od islamizacije Europe te je isticao da „pronatalitetnu politiku stavlja na prvo mjesto i najvažnije pitanje od nacionalnog interesa“, pozivajući „sve kršćanske zemlje Europe da učine isto. Pravom demografskom politikom moguće je zaustaviti umiranje kršćanske populacije ali reagirati treba odmah danas... Sutra će biti prekasno...". ${ }^{154}$ Može se s razlogom smatrati da je HSP, kao i druge stranke radikalne desnice, sklon teorijskom okviru zavjere „Eurabija“, koja smatra da postoji urota arapskog svijeta i zapadnoeuropske političke elite o planskom naseljavanju muslimana u kršćansku Europu, koja bi tako postala islamska kolonija. ${ }^{155} \mathrm{HSP}$ se zbog ,islamizacije“ otvoreno prikazivao braniteljem kršćanstva, pozivajući vladajuću političku elitu da podigne visok stupanj pripravnosti hrvatske policije, vojske i obavještajnih službi zbog imigranata. „Hrvatska je oduvijek bila predziđe kršćanstva i Hrvatska se opet nalazi na braniku kršćanske Europe htjeli mi to ili ne i u tome ćemo ostati apsolutno sami kao i mnogo puta u našoj prebogatoj povijesti““. ${ }^{156}$ Nadalje, otvoreno se govorilo i o sukobu civilizacija. ,....sve te 'izbjeglice' čak i kada bi sve od reda bile primljene u Europu imaju i jezičnu i kulturološku barijeru integriranja u zemlje Europe! Njihova prilagodba trajala bi vječno, a kulturološke promjene kod njih se ne bi nikad niti dogodile!“. ${ }^{157}$ Kritiziralo se i to što imigranti ne odlaze u bogate islamske države. „Niti jedan od tih 'izbjeglica' nije se odlučio izbjeći u neku PREBOGATU islamsku državu, a ima ih PREGRŠT! Nitko ne odlazi u Južnu Arabiju, Quatar, Oman, Bahrein, Kuwait! Mogu li ih oni primiti? NARAVNO! Imaju li jezičnu i kulturološku barijeru izbjeglice? NEMAJU! Dakle, što onda

152 Srb: Pod hitno podignimo zid ili postajemo sabirni centar za izbjeglice. Slobodna Dalmacija, 20. listopada 2015. https://slobodnadalmacija.hr/novosti/hrvatska/clanak/id/290284/srb-podhitno-podignimo-zid-ili-postajemo-sabirni-centar-za-izbjeglice (posjet 2. 7. 2018).

$153 \mathrm{http}: / /$ www.hsp.hr/vijesti/hsp-hoce-li-hrvatska-postati-islamska-republika-croatistan/ (posjet 2. 7. 2018).

154 http://www.hsp.hr/vijesti/alarmantno-upozorenje-krscanska-europa-umire-je-li-vec-prekasno/ (posjet 2. 7. 2018).

155 ZGURIĆ 2014: 106.

156 http://www.hsp.hr/vijesti/njemacka-zatvorila-svoje-granice-hrvatska-na-braniku-krscanskeeurope/ (posjet 2. 7. 2018).

157 http://www.hsp.hr/vijesti/islamizacija-europe/ (posjet 2. 7. 2018). 
goni te ljude na iseljenje u Europu?"“. ${ }^{158}$ U konačnici, u HSP-u uspoređivali su migracijsku krizu s Domovinskim ratom, naglašavajući da mi, Hrvati, ,iz svoje domovine nismo bježali, ostali smo se boriti za svoj dom“, pozivajući mahom mlade, radno i ratno sposobne imigrante: „,vratite [se] u svoju domovinu i obranite ju od svog neprijatelja, mi vam ovdje nemamo što pružiti“. ${ }^{159}$ Vidljivo je kako su u tom trenutku ključni „opasni Drugi“ bili muslimanski migranti s Bliskog istoka, a ne Srbi, odnosno srpska politička elita u Hrvatskoj. Međutim, takva ideologija nije imala uspjeha među hrvatskim biračima.

\section{Zaključak}

Analiza političke ideologije i djelovanja HSP-a empirijski je pokazala da je ta stranka tipski primjer radikalno desne stranke, prema teorijskom okviru Casa Muddea. Nativizam je imao značajnu ulogu u programu i djelovanju HSP-a koja je smatrala da je odnos Hrvata i Srba najozbiljniji problem hrvatske države. Stav HSP-a prema politici srpske političke elite polazio je od argumentacije kako Srbi uglavnom ne prihvaćaju hrvatsku državu, nego da je mrze, a da prihvaćaju samo hrvatske novce, beneficije i davanja, ali nikad hrvatsku državu. Riječju, Srbi odnosno, preciznije, srpska politika - bili su „opasni Drugi“, trajni neprijatelj, opasnost i prijetnja hrvatskoj državi te su narušavali homogenost hrvatske nacije. Tome treba dodati i seksualne manjine, a u novije vrijeme i muslimanske imigrante te vanjske neprijatelje kao što su MKSJ i EU. Autoritarnost u programu i djelovanju HSP-a podrazumijevala je vjeru u čvrsto organizirano društvo, dok se njegovo nepoštovanje trebalo oštro kazniti. HSP je zastupao jačanje oružanih snaga i policije, ističući da Hrvatska bez njih ne može zajamčiti unutarnju sigurnost neophodnu za razvoj i napredak kako bi postala zemlja u kojoj su u punini ostvareni nacionalni interesi hrvatskog naroda. To je u neku ruku vodilo ka prihvaćanju militarističkih pogleda, ideji da se svakog građanima u ratu, ali i izvan njega treba tretirati kao na vojnika. To i ne začuđuje s obzirom na to da je HSP bio ratnička stranka na početku 1990-ih, spremna da se na izravniji način uključi u oružane sukobe. Osim toga, stranka je vjerovala da bi strože kazne djelovale preventivno u szubijanju kriminala, te je podupirala neovisniji i snažniji pravosudni sustav. Nerijetko su u svojim nastupima pravaški prvaci predlagali kastraciju za pedofile, a tijekom Domovinskog rata znala se spominjati i smrtna kazna za one koji su počinili zločin nad hrvatskim narodom. Tome valja dodati da je HSP oštro istupao protiv pobačaja te se istodobno zalagao za pronatalitetnu politiku i jačanje institucije braka i obitelji koje moraju počivati na kršćanskim temeljima. U konačnici, treba spomenuti i stranačku organizaciju te iznimno

158 Isto.

159 http://www.hsp.hr/vijesti/poruka-hsp-a-ili-nas-postujte-ili-zaobidite/ (posjet 2. 7. 2018). 
prezidencijalistički položaj predsjednika stranke, koji je započeo još s Paragom u ratnoj 1991., da bi se nastavio s Đapićem nakon raskola tijekom cijele njegove vladavine. Obojica pravaških lidera koncentrirala su moć političko-stranačkog odlučivanja u svojim rukama, personalizirajući se u političkoj komunikaciji. Riječju, autoritarnost HSP-a uključuje autoritet vođe i hijerarhiju, čvrst „zakon i red“ te "tradicionalni kazneni moralizam“.

Populizam je kao politička ideologija također nazočan u HSP-u. Njegovi su prvaci sebe proglašavali jedinim pravim demokratima i iskazom prave narodne volje. Oni su ti koji predstavljaju narod, nasuprot „pokvarene“ elite. U hrvatskome slučaju, za njih su tu elitu predstavljale prvenstveno etablirane stranke HDZ i SDP. To je pogotovo vidljivo bilo u izbornim kampanjama 2007. i 2011., kada su potonje, kao nositelji političke elite, od strane HSP-a proglašene ,sijamskim blizancima" koji su izdali hrvatske nacionalne interese. Štoviše, HSP je izričito smatrao da elite nisu napravile rez $\mathrm{s}$ komunističkom prošlošću, da se u prvim dvama desetljećima hrvatske samostalnosti ništa značajno nije promijenilo te da su stare elite zapravo uspjele sačuvati svoju moć i položaje. HSP je bio deklarativno istinski primjer antikomunističke stranke, smatrajući da društvene promjene iz 1990. ipak nisu bile dovršene. Prema uvjerenju pravašâ, iako je završeno s komunističkom diktaturom, nije završeno s komunistima koji su nastavili svoje djelovanje u novim, demokratskim uvjetima. Stoga ne iznenađuje inzistiranje HSP-a na donošenju lustracijskog zakona. Unatoč tome, treba istaknuti da je međusoban odnos HSP-a i HDZ-a, koji je vremenski najduže vladao državom, varirao. Tako je HSP pod vodstvom Parage tijekom uspostave i stvaranja samostalne države radikalno kritizirao politiku koju je provodio HDZ na čelu s Franjom Tuđmanom, optužujući ga, primjerice, za pad Vukovara, tromost u obrani države ili podjelu $\mathrm{BiH}$. Nakon pravaškog raskola i preuzimanja HSP-a, Đapić i stranka su u svojem djelovanju izostavili spomenute kritike i optužbe na račun vladajuće političke elite na čelu s Tuđmanom, djelujući u stranačkom sustavu kao lojalna oporba, zbog čega možemo govoriti o krnjem populizmu. U tom je smislu inzistiranje na lustraciji tijekom 1990-ih također variralo. Pod vodstvom Parage, stranka je bila za apsolutnu lustraciju. S druge strane, nakon raskola, stranka je pod vodstvom Đapića, iako podržavajući i zalagajući se za lustraciju, bila za njezinu selektivnu primjenu u smislu da se ona ne bi odnosila na one koji su tijekom komunističke diktature sudjelovali u stvaranju samostalne hrvatske države ili su bili disidenti. Kritika na račun HDZ-a ponovno se aktivirala krajem 2003. nakon neuspjelog pokušaja da HSP postane dio vladajuće većine, i bila je nakon toga u kontinuitetu.

Populizmu HSP-a treba pridodati i pozivanje na provedbu referenduma i podnošenje različitih peticija, što je trebalo predstavljati oblike izravne demokracije. Zbog takve radikalno desne ideologije HSP nikad nije bio prihvatljiv koalicijskim partnerima u sastavljanju vlasti. Tijekom 1990-ih nije ni bio u mogućnosti približiti se vlasti zbog dominacije HDZ-a. Na prijelazu u 21. stoljeće bio je na suprotnim 
ideološkim pozicijama naspram vladajuće većine koju je predvodio lijevi SDP, a jedina je prilika za suradnju bila 2003., međutim, koalicijski potencijal HSP-a nije iskorišten zbog pritisaka iz međunarodne zajednice. Može se stoga zaključiti da je HSP ipak bio, promatrajući s gledišta zauzimanja položaja u vlasti, irelevantna stranka na razini hrvatske države tijekom prva dva i pol desetljeća samostalnosti. Razlozi izbornih neuspjeha mogu se tražiti i u rascjepkanosti pravaških stranaka koje time nisu u mogućnosti kapitalizirati svoju politiku, za razliku od srodnih joj stranaka radikalne desnice u zemljama EU-a te u Europskom parlamentu, kao što su, primjerice, francuska Nacionalna fronta, Slobodarska stranka Austrije, Jobbik, talijanska Liga, Alternativa za Njemačku ili nizozemska Slobodarska stranka. Kao stranka radikalne desnice, HSP je djelovao u okviru demokratskog sustava na njegovim marginama bez nekog izraženog izbornog rezultata, prihvaćajući temeljne vrijednosti demokratskog poretka.

\title{
Bibliografija
}

\author{
Kratice \\ $\mathrm{BiH}$ - Bosna i Hercegovina \\ EU - Europska unija \\ HDZ - Hrvatska demokratska zajednica \\ HKDU - Hrvatska kršćanska demokratska unija \\ HNS - Hrvatska narodna stranka \\ HOS - Hrvatske obrambene snage \\ HSP - Hrvatska stranka prava \\ MKSJ - Međunarodni kazneni sud za bivšu Jugoslaviju \\ NDH - Nezavisna Država Hrvatska \\ SAO - Srpska autonomna oblast \\ SDP - Socijaldemokratska partija \\ SDS - Srpska demokratska stranka \\ SDSS - Samostalna demokratska srpska stranka \\ SUDHOS - Savez udruga dragovoljaca HOS-a
}

\section{Neobjavljeni izvori}

Osobna pismohrana Stjepana Špehara (OPSŠ), Feričanci, Hrvatska.

Pismohrana Hrvatske stranke prava (PHSP), Zagreb, Hrvatska.

\section{Dokumenti}

Izvješća Hrvatskog sabora, Zagreb, Hrvatska. 


\section{Periodika}

Danas, Zagreb

Jutarnji list, Zagreb

Novi Vjesnik, Zagreb

Slobodna Dalmacija, Split

Večernji list, Zagreb

Vjesnik, Zagreb

\section{Literatura}

BADOVINAC, Tomislav. 2015. Neofašizam - društveni korijeni, politički oblici, ideološki sadržaj. U Neofašizam - korijeni, oblici, sadržaji, ur. Tomislav Badovinac, Dragutin Lalović, 9-13. Zagreb: Društvo Povijest izvan mitova.

BALABANIĆ, Ivan, Marko MUSTAPIĆ. 2008. Medijska retorika u predizbornom razdoblju. 2007. Analiza dnevnog tiska. Društvena istraživanja 17/4-5: 647-669.

BARANOVIĆ, Branislava. 1995. Izbori '95 na Hrvatskoj televiziji i u novinama. Medijska istraživanja 1/2: 163-182.

BEYME, Klaus von. 2007. Populism and right-wing extremism in modern democracies. U Populism in Central Europe, ur. Václav Nekvapil, Maria Staszkiewicz, 26-40. Prague: Association for International Affairs.

BLAŽEKOVIĆ, Goran Ante. 2007. Hrvatska stranka prava 1990. godine: Obnova, djelovanje i uzroci raskola. U Pravaška misao i politika: zbornik radova, ur. Jasna Turkalj, Zlatko Matijević, Stjepan Matković, 301-317. Zagreb: Hrvatski institut za povijest.

BURNHAM, Peter, Karin GILLAND, Wyn GRANT, Zig LAYTON-HENRY. 2006. Metode istraživanja politike. Zagreb: Fakultet političkih znanosti.

BUTKOVIĆ, Davor, Marijan GRAKALIĆ. 1992. Domovinski rat: interview. Zagreb: Azur journal.

ESTERAJHER, Josip. 2012. Ideologija desnog radikalizma u Srbiji. Doktorska disertacija, Fakultet političkih znanosti Sveučilišta u Zagrebu.

GOLDSTEIN, Ivo. 2011. Povijest Hrvatske 1945-2011. 3. svezak: 1991-2011. Zagreb: EPH.

GRDEŠIĆ, Ivan. 1999. The Radical Right in Croatia and its Constituency. U The Radical Right in Central and Eastern Europe since 1989, ur. Sabrina P. Ramet, 171-189. University Park: The Pennsylvania State University Press.

JONJIĆ, Tomislav. 2013. Sporovi i rascjepi u obnovljenoj Hrvatskoj stranci prava 1990.-1992. U Pravaštvo u hrvatskome političkom i kulturnom životu u sučelju dvaju stoljeća, ur. Zdravka Jelaska-Marijan, Zlatko Matijević, 541-563. Zagreb: Hrvatski institut za povijest.

JOVIĆ, Dejan. 2017. Rat i mit. Politika identiteta u suvremenoj Hrvatskoj. Zagreb: Fraktura. 
JOŽANC, Nikolina, Višeslav RAOS. 2011. Internet and Radical Political Groups in Croatia. U Information Society and Globalization: Transformation of Politics, ur. Jan Van Dijk, Nikolina Jožanc, 209-239. Zagreb: Centar za politološka istraživanja.

LALOVIĆ, Dragutin. 2015. Fašistička lijepa država. Mussolinijev izum revolucionarne desnice. U BADOVINAC I LALOVIĆ 2015: 17-48.

LAMZA POSAVEC, Vesna. 2006. Metode istraživanja: skripta za studente politologije. Zagreb: Fakultet političkih znanosti.

LUČIĆ, Ivica. 2016. Političko-sigurnosne okolnosti pogibije Ante Paradžika. Časopis za suvremenu povijest 48/2: 355-388.

MILARDOVIĆ, Anđelko. 1997. Uvod u politologiju. Osijek: Pan liber.

MILARDOVIĆ, Anđelko. 2004. Populizam i globalizacija. Zagreb: Centar za politološka istraživanja.

MUDDE, Cas. 2000. The ideology of the extreme right. Manchester-New York: Manchester University Press.

MUDDE, Cas. 2007. Populist Radical Right Parties in Europe. Cambridge: Cambridge University Press.

MUDDE, Cas. 2014. Krajnja desnica na europskim izborima 2014. godine: nešto novoga, mnogo staroga. Političke analize 18: 13-19.

MUDDE, Cas, Cristóbal Rovira KALTWASSER. 2013. Populism. U The Oxford Handbook of Political Ideologies, ur. Michael Freeden, Lyman Tower Sargent, Marc Stears, 493-512. Oxford: Oxford University Press.

OBUĆINA, Vedran. 2012. Right-Wing Extremism in Croatia. Digitale Bibliothek der Friedrich-Ebert-Stiftung. International Policy Analysis. http://library.fes.de/pdf-files/ id-moe/09346.pdf (posjet 9. 6. 2018).

PARAGA, Dobroslav, Ante PARADŽIK. 1991. Borba za hrvatsku državnu nezavisnost - od obnove do Lipanjske povelje Hrvatske stranke prava. Zagreb: HSP.

PAVELIĆ, Krešimir. 1995. HSP od obnove do slobode: politikanti, karijeristi, demagozi, pseudopravaši, masoni i kosovci. Zagreb: HDSP.

PAVLAKOVIĆ, Vjeran. 2008. Opet Za dom spremni. Desetotravanjske komemoracije u Hrvatskoj nakon 1990. godine. U Kultura sjećanja: 1941. Povijesni lomovi i svladavanje prošlosti, ur. Sulejman Bosto, Tihomir Cipek, Olivera Milosavljević, 113-129. Zagreb: Disput.

ROHAČEK, Goran. 2009. Hrvatsko pravaštvo na prijelazu tisućljeća. Čakovec: Vlastita naklada.

ŠALAJ, Berto. 2013. Jesu li Hrvatski laburisti populisti i je li populizam nužno loš?. Političke analize 4/13: 17-22.

TURKOVIĆ, Vera. 2009. Vizualna/likovna (ne)pismenost političkih stranaka u Hrvatskoj. Politička misao 46/1: 114-134.

VESELINOVIĆ, Velimir. 2014. Obnavljanje i djelovanje Hrvatske stranke prava, 19901992. Politička misao 51/2: 55-87.

VESELINOVIĆ, Velimir. 2015. Politička djelatnost Ante Paradžika. Anali Hrvatskog politološkog društva 12/1: 133-55. 
VESELINOVIĆ, Velimir. 2016. Franjo Tuđman i pravaši. Politička misao 53/1: 71-102.

VESELINOVIĆ, Velimir. 2017. Desne političke stranke: ideologija, pojmovi, vrste. $\mathrm{Me}$ đunarodne studije 16/1: 55-83.

VESELINOVIĆ, Velimir. 2018. Hrvatska stranka prava u suvremenoj Hrvatskoj od 1990. do 2011. Doktorska disertacija, Fakultet političkih znanosti Sveučilišta u Zagrebu.

YIN, Robert K. 2007. Studija slučaja - dizajn i metode. Zagreb: Fakultet političkih znanosti.

ZAKOŠEK, Nenad. 2002. Politički sustav Hrvatske. Zagreb: Fakultet političkih znanosti. ZGURIĆ, Borna. 2014. Stranke radikalne desnice: mađarski Jobbik i nizozemska Slobodarska stranka. Politička misao 51/4: 90-113.

\section{Elektronički izvori}

arhiv HRTweb vijesti od 1. sibnja 1998. do 4. listopada 2005. http://www.hrt.hr/arhiv/ (posjet 29. 12. 2015).

portal AIM. http://www.aimpress.ch/ (posjet 2. 7. 2018).

portal Jutarnji list. http://www.jutarnji.hr/ (posjet 2. 7. 2018).

portal Slobodna Dalmacija. http://www.slobodnadalmacija.hr/ (posjet 2. 7. 2018).

portal Večernji list. http://www.vecernji.hr/ (posjet 2. 7. 2018).

Službena stranica HSP-a. http://www.hsp.hr/ (posjet 2. 7. 2018).

Zagrebački HSP: „Uskratite paradi pažnju! Roditelji, sklonite svoju djecu da ne gledaju kršenje morala“. Index.hr, 17. 6. 2011. http://www.index.hr/vijesti/clanak/zagrebacki-hsp-uskratite-paradi-paznju-roditelji-sklonite-svoju-djecu-da-ne-gledaju-krsenjemorala/557158.aspx (posjet 2. 7. 2018).

„Himna HOS-a“. https://www.youtube.com/watch?v=TqzXImf_86Q (posjet 2. 7. 2018). 


\section{The ideology of the populist radical right in Croatia: case study of the Croatian Party of Rights}

Based on the archival materials, press analysis and the review of the relevant works on the subject, the author analyses and presents the ideology of the Croatian Party of Rights (HSP) - not only a pivotal rightism party, but also a right-wing party in the Croatian political life and the party system. Once the multi-party system was established, HSP was rebuilt by former political prisoners and dissidents Dobroslav Paraga and Ante Paradžik. The main party's agenda was the establishment of an independent Croatian state. The article deals with the study of a period of renewal HSP from the early 1990s to 2015. The article is divided into six parts. In the first part, the author presents the contemporary ideology of the radical right. Contemporary radical right-wing political parties are not necessarily anti-systemic, but they are mainly ultra-nationalistic, xenophobic, homophobic and populist. The second part of the article refers to the methodology and objectives of the research. In the remaining chapters of the article, by using the theoretical framework of the Dutch political scientist Cas Mudde concerning the ideology of the radical right made up of nativism, authoritarianism and populism, the author concludes that HSP meets all three criteria of right-wing radicalism, and that it can be considered a radical right-wing party. The analysis confirms the assumption that HSP is a populist option. The author suggests that HSP is best described as a combination of right-wing populists focused on the "dangerous Others", i.e. Serbs, especially the policy of the Serbian political elite in Croatia and Muslim immigrants from the Middle East, and an anti-establishment reform party.

Keywords: radical right, nativism, authoritarianism, populism, Croatian Party of Rights.

Ključne riječi: radikalna desnica, nativizam, autoritarnost, populizam, Hrvatska stranka prava.

Velimir Veselinović

Fakultet političkih znanosti Sveučilišta u Zagrebu Lepušićeva 6, HR-10000 Zagreb veselinovic.velimir@gmail.com 


\section{FILOZOFSKI FAKULTET SVEUČILIŠTA U ZAGREBU \\ ZAVOD ZA HRVATSKU POVIJEST \\ INSTITUTE OF CROATIAN HISTORY \\ INSTITUT FÜR KROATISCHE GESCHICHTE}

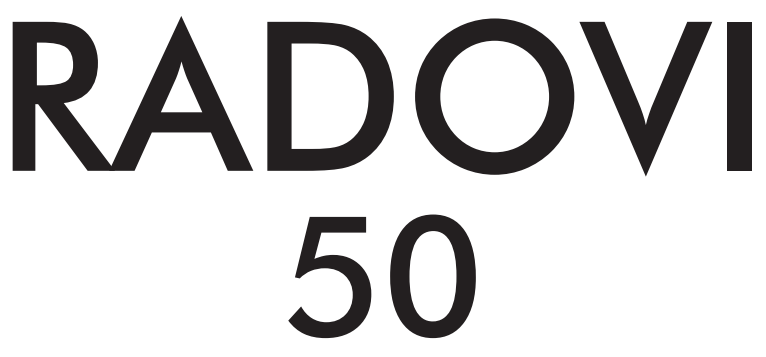

BROJ 2

ZAVOD ZA HRVATSKU POVIJEST

FILOZOFSKOGA FAKULTETA SVEUČILIŠTA U ZAGREBU

\section{FF press}

ZAGREB 2018. 


\title{
RADOVI ZAVODA ZA HRVATSKU POVIJEST FILOZOFSKOGA FAKULTETA SVEUČILIŠTA U ZAGREBU
}

\author{
Knjiga 50, broj 2
}

\author{
Izdavač / Publisher \\ Zavod za hrvatsku povijest \\ Filozofskoga fakulteta Sveučilišta u Zagrebu \\ FF-press \\ Za izdavača / For Publisher \\ Vesna Vlahović Štetić \\ Glavni urednik / Editor-in-Chief \\ Hrvoje Gračanin \\ Izvršni urednik / Executive Editor \\ Nikola Anušić \\ Uredništvo / Editorial Board
}

Bruna Kuntić-Makvić (stara povijest/ancient history), Zrinka Nikolić Jakus (srednji vijek/

medieval history), Hrvoje Petrić (rani novi vijek/early modern history), Željko Holjevac (moderna povijest/modern history), Tvrtko Jakovina (suvremena povijest/contemporary history),

Silvija Pisk (mikrohistorija i zavičajna povijest/microhistory and local history),

Zrinka Blažević (teorija i metodologija povijesti/theory and methodology of history)

Međunarodno uredničko vijeće / International Editorial Council

Denis Alimov (Sankt Peterburg), Živko Andrijašević (Nikšić), Csaba Békés (Budapest), Rajko Bratož (Ljubljana), Snježana Buzov (Columbus, Ohio), Svetlozar Eldarov (Sofija), Toni Filiposki

(Skopje), Aleksandar Fotić (Beograd), Vladan Gavrilović (Novi Sad), Alojz Ivanišević (Wien),

Egidio Ivetić (Padova), Husnija Kamberović (Sarajevo), Karl Kaser (Graz),

Irina Ognyanova (Sofija), Géza Pálffy (Budapest), Ioan-Aurel Pop (Cluj),

Nade Proeva (Skopje), Alexios Savvides (Kalamata), Vlada Stanković (Beograd),

Ludwig Steindorff (Kiel), Peter Štih (Ljubljana)

Izvršni urednik za tuzemnu i inozemnu razmjenu /

Executive Editor for Publications Exchange

Martin Previšić

Tajnik uredništva / Editorial Board Assistant

Dejan Zadro

Adresa uredništva/Editorial Board address

Zavod za hrvatsku povijest, Filozofski fakultet Zagreb, Ivana Lučića 3, HR-10 000, Zagreb

Tel. ++385 (0)1 6120 150, 6120 158, faks ++385 (0)1 6156879

Časopis izlazi jedanput godišnje / The Journal is published once a year

Časopis je u digitalnom obliku dostupan na / The Journal in digital form is accessible at

Portal znanstvenih časopisa Republike Hrvatske „Hrčak“ http://hrcak.srce.hr/radovi-zhp

Financijska potpora za tisak časopisa / The Journal is published with the support by Ministarstvo znanosti, obrazovanja i športa Republike Hrvatske

Časopis je indeksiran u sljedećim bazama / The Journal is indexed in the following databases: Directory of Open Access Journals, EBSCO, SCOPUS, ERIH PLUS, Emerging Sources Citation Index - Web of Science 


\title{
Naslovna stranica / Title page by
}

Iva Mandić

\section{Grafičko oblikovanje i računalni slog / Graphic design and layout Marko Maraković}

\author{
Lektura / Language editors \\ Samanta Paronić (hrvatski / Croatian) \\ Dražen Nemet (engleski / English)
}

Tisak / Printed by

Tiskara Zelina, Sv. Ivan Zelina

Naklada / Issued

200 primjeraka / 200 copies

Časopis je u digitalnom obliku dostupan na Portalu znanstvenih časopisa Republike Hrvatske „Hrčak“ http://hrcak.srce.hr/radovi-zhp

The Journal is accessible in digital form at the Hrcak - Portal of scientific journals of Croatia http://hrcak.srce.hr/radovi-zhp 